\title{
The impact of reactive oxygen species in the development of cardiometabolic disorders: a review
}

\author{
Roland Akhigbe ${ }^{1,2,3}$ (D) and Ayodeji Ajayi ${ }^{1 *}$ (D)
}

\begin{abstract}
Oxidative stress, an alteration in the balance between reactive oxygen species (ROS) generation and antioxidant buffering capacity, has been implicated in the pathogenesis of cardiometabolic disorders (CMD). At physiological levels, ROS functions as signalling mediators, regulates various physiological functions such as the growth, proliferation, and migration endothelial cells (EC) and smooth muscle cells (SMC); formation and development of new blood vessels; EC and SMC regulated death; vascular tone; host defence; and genomic stability. However, at excessive levels, it causes a deviation in the redox state, mediates the development of CMD. Multiple mechanisms account for the rise in the production of free radicals in the heart. These include mitochondrial dysfunction and uncoupling, increased fatty acid oxidation, exaggerated activity of nicotinamide adenine dinucleotide phosphate oxidase (NOX), reduced antioxidant capacity, and cardiac metabolic memory. The purpose of this study is to discuss the link between oxidative stress and the aetiopathogenesis of CMD and highlight associated mechanisms.

Oxidative stress plays a vital role in the development of obesity and dyslipidaemia, insulin resistance and diabetes, hypertension via various mechanisms associated with ROS-led inflammatory response and endothelial dysfunction.
\end{abstract}

Keywords: Free radicals, OxLDL, PDGF, IGF, NOS uncoupling, ROS

\section{Introduction}

Cardiometabolic disorders (CMD) is a constellation of metabolic predisposing factors for atherosclerosis such as insulin resistance (IR) or diabetes mellitus (DM), systemic hypertension, central obesity, and dyslipidaemia [1]. They contribute to the global death rate and remain a public health challenge. There is a significant rise in the prevalence of CMD not only in high-resource countries but also in developing nations with emerging economies $[2,3]$. Although, there are available data on the development of CMD and the mechanisms associated with its attendant complications, novel mechanisms are

\footnotetext{
* Correspondence: jy_ayodeji@gmail.com

${ }^{1}$ Department of Physiology, College of Medicine, Ladoke Akintola University of Technology, Ogbomoso, Oyo State, Nigeria

Full list of author information is available at the end of the article
}

still revealed by recent studies in an attempt to open new therapeutic opportunities $[4,5]$. Several studies have implicated oxidative stress in CMD development. It has been reported that cardio-tolerance to oxidative stress reduces with advancing age due to the antioxidant levels, particularly enzymatic antioxidants, contributing to the development of CMD [6]. Also, this has been linked with arterial thickening and atherosclerosis [7, 8]. This ensues in vascular endothelial damage and remodelling.

The high prevalence of CMD is a global phenomenon. The increase in the global prevalence is seemingly due to a parallel rise in the incidence of dietary and lifestyle changes, and cases of obesity [9]. There is an anticipated increase in these disorders due to projections of a greater incidence in future obesity cases [9]. The increased incidence of CMD among urban women when compared with their rural counterparts has been 
attributed to the global increase in urbanization and decline in physical exercise, especially in Africa [10]. A Nigerian study reported a prevalence of $18.0 \%$ and $10.0 \%$ in the semi-urban and rural community respectively and $34.7 \%$ and $24.7 \%$ respectively in a hypertensive population [11]. In Tunisia, Hosseinpanah et al. [12] documented a prevalence of $55.8 \%$ and $30.0 \%$ in women and men respectively. The higher prevalence in women was ascribed to the lower high-density lipoprotein (HDL), higher incidence of central obesity, and hypertension. According to the findings of Harzallah in Turkey [13], though female had a higher prevalence (39.6\%) than the male counterpart (28\%), the prevalence was similar in the urban (33.8\%) and rural (33.9\%) settings. In Qatar, prevalence rate of 26.5\% was reported using Adult Treatment Panel III (ATP III) criteria and 33.7\% using International Diabetes Foundation (IDF) criteria [14]. The observed incidence rose with advancing age and increasing body mass index, but reduced advancement in education and regular physical activity. In Lebanon, a prevalence of $31.2 \%$ was reported with men having a striking higher tendency [15]. Sibai [16] documented an age-adjusted prevalence of 37\% in males in Saudi Arabia, with a higher prevalence in male (44\%) than female (35.6\%) [16]. In the USA in 2003/2004, using the National Cholesterol Education Program (NCEP)/ATP III criteria, about 34\% people above 20 years old had CMD [17], with a marginal higher prevalence in male $(35.1 \%)$ than female (32.6\%). Although the prevalence of the disorder varies across geographic regions and age groups, about $25 \%$ of the adult European population was reported to have CMD [18].

This review highlights the role of ROS in the pathogenesis of CMD and discusses the associated mechanisms. This will shed more light to the pathogenesis of CMD and consequent open new therapeutic horizons.

\section{Methods}

The present study reviewed all available data published in peer-reviewed journals up till date. Search was made using AJOL, DOAJ, Embase, Google Scholar, Pubmed/ Pubmed Central, and Scopus databases using relevant key word searches like "Cardiometabolic disorders", "metabolic disorders", "Reactive oxygen species", "ROS", "oxidative stress", "lipid peroxidation", "Nitrosative stress", and "Antioxidants and cardiometabolic disorders". Papers published in peer-reviewed journals were included in this narrative review. Papers that did not adequately discuss details of the study were excluded from this review. Duplicated records were also excluded.

\section{Discussion}

\section{Pathophysiology of CMD}

CMD involve interplay of a cascade of pathophysiological events ensuing in a rise in IR, accumulation of free fatty acids (FFA) in the circulation, lipid and glucose dysmetabolism, and raised levels of adipokines and cytokines [1921]. Since insulin controls adipose tissue lipid breakdown, the primary source of plasma (FFA), excess visceral fat causes IR with a resultant increase in lipids breakdown [22]. IR is further triggered by the increasing FFA concentrations via enhanced glucose dysregulation [23, 24]. These cumulate in ladening of fatty deposits in the blood vessels with resultant vasoconstriction, excessive fluid retention, and sustained rise in blood pressure [22].

A raised level of FFA does not just prevent the stimulation of glucose uptake in the muscle by insulin, [25] it also depresses the production of glucose in the liver [26], and enhances hepatic uptake of FFA. It causes increased production of VLDL and triglyceride (TG) in the liver [27-30], thus promoting TG transfer from VLDL to HDL and subsequent clearance of HDL [29, 30].

Inflammatory cytokines are generated by the adipose tissue and have the potential to trigger IR and adiponectin $[31,32]$. Tumour necrosis factor-alpha (TNF- $\alpha$ ) suppresses insulin signalling [33], interleukin-6 (IL-6) directly induces inflammation or enhances the release of hepatic C-reactive protein [34], while interleukin-8 (IL8) activates neutrophil granulocytes. Adiponectin increases hepatic insulin sensitivity and oxidation of skeletal muscle glucose and fatty acid, and decreases glucose release [35-38]. This may infer that when there is abnormal plasma FFA concentration, the production of adipokines is raised while that of adiponectin is reduced.

Though obesity-associated excess visceral and/or intraperitoneal fat is strongly linked with IR $[25,26,39$, 40], whether or not intraperitoneal fat causes or is just associated with IR remains unclear. However, studies have suggested that fatty acids from lipolysis of intraperitoneal fat are a vital influential predisposing factor of IR since they are delivered to the liver directly through the portal vein [41]. Findings from the study of Havel et al. [42] among obese subjects revealed that lipolysis of the intraperitoneal fat accounts for $20 \%$ of FFA delivered to the liver and 15\% delivered to skeletal muscle. Thus, intraperitoneal fat possibly contributes to hepatic IR, but unlikely to trigger skeletal muscle IR.

The pathogenesis of CMD involves a complex interplay between genetics and environmental factors. Also, epigenetic factors such as DNA methylation and histone modification are possibly key in the incidence of these disorders by mediating the effects of environmental exposures on the risk of development of CMD. The genetic factors are primarily hereditary and non-modifiable, while the environmental factors are modifiable. Race and advancing age are additional non-modifiable factors. Table 1 shows a list of some modifiable factors. Individuals at risk could be influenced by one or more hereditary and environmental factors which may worsen the 
pathogenic progress [22]. Thus, lifestyle modifications like diet and weight control, optimal exercise, cessation of cigarette smoking, and control of pollution and exposure to other mitochondrial toxins are beneficial factors that assuage CMD development.

Epigenetics are alterations caused by developmental processes or environmental influences that do not modify the genetic code but influences the expression of the information encoded in the DNA [43]. Though there is limited evidence from genetic studies for a common genetic soil for CMD development, and contradicting relationships of genes and gene variants exists [44]. In order to promote early detection, prompt management and likely preventive strategies, a good an in-depth knowledge of the predisposing genetic factors influencing the development of CMD is important.

Table 1 Modifiable protective and risk factors for cardiometabolic disorders

\begin{tabular}{|c|c|c|c|}
\hline Risk Factors & Effects & Mechanisms & References \\
\hline Alcohol use disorders & $\longrightarrow$ & Impaired lipid profile & 205 \\
\hline Smoking & & $\begin{array}{l}\text { Oxidative stress, pro- } \\
\text { inflammatory, pro- } \\
\text { atherogenic, and pro- } \\
\text { thrombotic }\end{array}$ & 206 \\
\hline $\begin{array}{l}\text { Lack of sufficient } \\
\text { physical activity }\end{array}$ & & Impaired lipid profile & 207 \\
\hline Psychiatric disorders & & $\begin{array}{l}\text { Eating disorder, } \\
\text { sympathetic over- } \\
\text { activity, oxidative stress, } \\
\text { inflammation }\end{array}$ & 208 \\
\hline Chocolate consumption & & $\begin{array}{l}\text { Anti-oxidant, anti- } \\
\text { inflammatory, anti- } \\
\text { atherogenic, and anti- } \\
\text { thrombotic }\end{array}$ & 209,210 \\
\hline $\begin{array}{l}\text { Childhood and } \\
\text { adolescent adversity }\end{array}$ & & - & 211 \\
\hline Vitamin D & & $\begin{array}{l}\text { Enhanced glucose utility, } \\
\text { improved lipid profile, } \\
\text { regulation of intracellular } \\
\text { and extracellular } \\
\text { calcium, anti- } \\
\text { inflammatory }\end{array}$ & 212 \\
\hline $\begin{array}{l}\text { Consumption of fast } \\
\text { foods }\end{array}$ & & $\begin{array}{l}\text { Impaired insulin and } \\
\text { glucose homeostasis, } \\
\text { lipid and lipoprotein } \\
\text { disorders, induction of } \\
\text { systemic inflammation } \\
\text { and oxidative stress }\end{array}$ & 213 \\
\hline $\begin{array}{l}\text { Traffic-related } \\
\text { particulate matters }\end{array}$ & & $\begin{array}{l}\text { Altered cardiac } \\
\text { autonomic function, } \\
\text { vaso-constriction }\end{array}$ & 214 \\
\hline
\end{tabular}

$\longrightarrow \quad$ : negative effect of risk factor

: positive effect of protective factor 


\section{Oxidative stress}

Oxidative stress (OS) is the presence of reactive oxygen species (ROS) in excess of the antioxidant buffering capacity. It can be described as an imbalance in ROS generation and antioxidant defence leading to accumulation of ROS. It is an alteration in the balance of prooxidant /antioxidant system in favour of prooxidant with attendant lethal effects with resultant damage to the cellular macromolecules (Fig. 1). In organisms, including humans, ROS and free radicals are produced during metabolic and immune system function. Molecular oxygen $\left(\mathrm{O}_{2}\right)$ can unpair and leave free radicals which are highly unstable and reactive, leading to the formation of $\operatorname{ROS}[45,46]$.

Free radicals are molecules with at least one unpaired electrons in their outer orbit. This makes them highly unstable and reactive with other molecules to produce more stable species [47]. Such radicals include Reactive Oxygen Species (ROS) and Reactive Nitrogen Species (RNS) [48]. Free radicals and oxidant species are involved in cellular and tissue dysfunction, and thus toxic [49]. Although low or moderate concentrations of these molecules play physiological roles such as signalling processes and defence mechanisms against infectious agents [49], when they are generated in excess, they lead to lipid, protein and DNA damage. This is a known fact, though stunning that ROS protects the cell against ROS damage by stimulating antioxidant responses and maintaining or re-establishing redox balance. It is noteworthy to state that in non-pathological states, ROS in low to moderate concentrations play a key homeostatic function in cellular and mitochondrial signaling and functionality; but, in excess concentrations when unchecked, it mediates oxidative cell and tissue damage. This can trigger positive feedback [50].

\section{Sources of cardiovascular ROS Sources of ROS in cells}

Vascular cells, including cardiac cells and neurons, generate ROS, thus triggering the incidence of CMD.

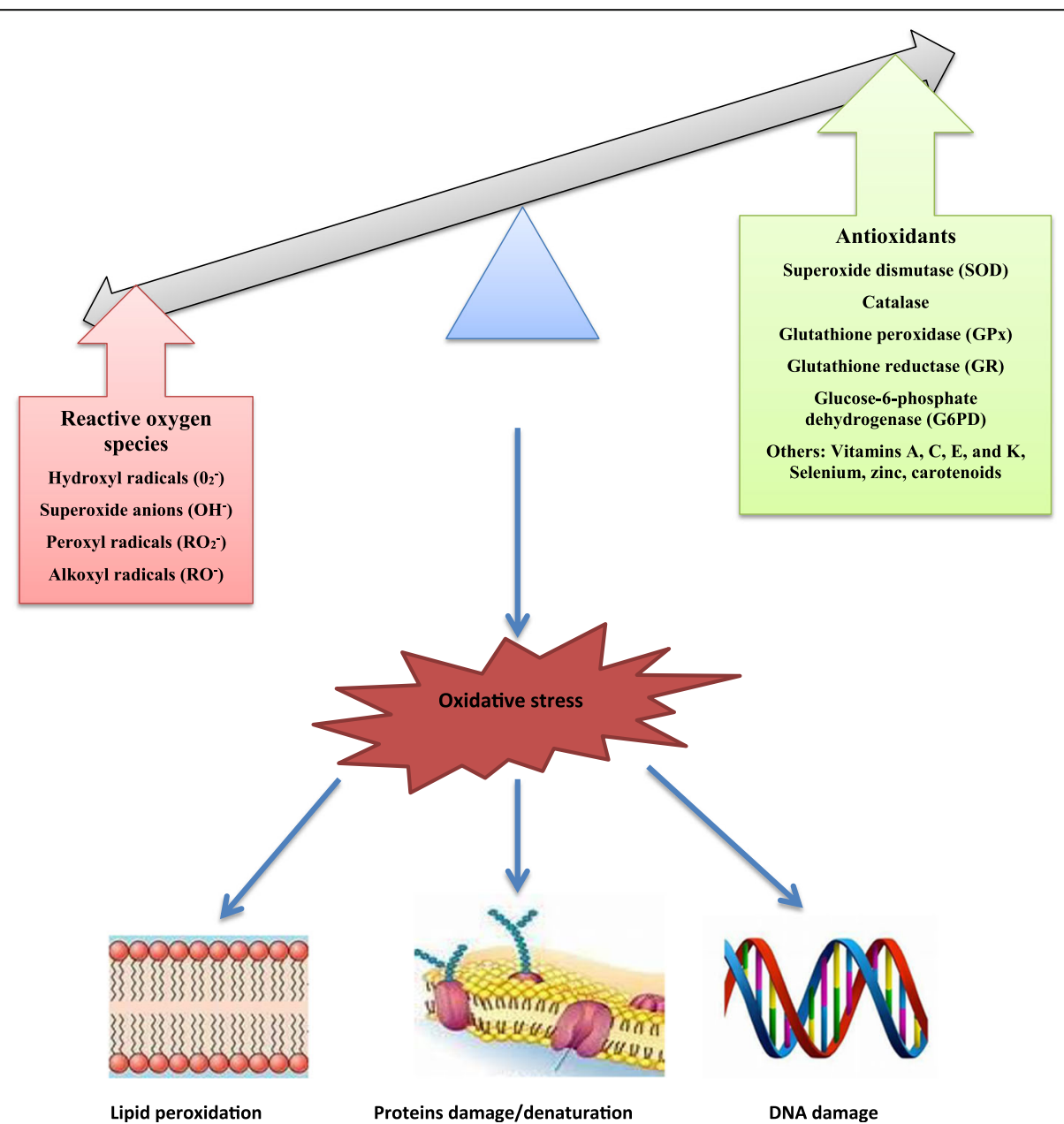

Fig. 1 Oxidative stress resulting from an imbalance between ROS generation and antioxidant system and its consequences on cellular macromolecules 
Various enzyme systems such as cytochrome P450, the mitochondrial respiratory chain, xanthine oxidase (XO), uncoupled endothelial nitric oxide synthase (eNOS), heme oxygenase $(\mathrm{HO})$, myeloperoxidase (MPO), lipoxygenase (LOX), cyclooxygenase (COX) and NADPH oxidases (NOX) generate ROS especially in a pathological state [51].

$\mathrm{XO}$ is a xanthine oxidoreductase that exists in two forms; xanthine dehydrogenase $(\mathrm{XDH})$, which is the predominant form and can be irreversibly or reversibly converted into $\mathrm{XO}$ via proteolysis or the oxidation of cysteine residues respectively [52]. Its expression in the vascular endothelium is promoted by angiotensin II (Ang II) or oscillatory shear in a NOX-dependent manner [53].

The NOX family includes NOX1-5 and DUOX1-2. In humans, NOX2 NADPH oxidase seems to be the most important source of ROS generation [54-56]. NADPH oxidases are specific source of ROS because they produce ROS in a tightly-controlled manner unlike as in other sources where ROS are produced as a secondary metabolite [57]. Also, NADPH oxidases can also generate ROS from other enzyme systems [57].

Superoxide radical $\left(\mathrm{O}_{2}^{-}\right)$is the first moiety that is produced by most of the enzyme systems, particularly NADPH oxidases. $\mathrm{O}_{2}{ }^{-}$radical can undergo rapid dismutation to hydrogen peroxide $\left(\mathrm{H}_{2} \mathrm{O}_{2}\right)$, which is mediates most signaling effects of ROS [57].

\section{ROS in the heart}

Excessive ROS generation in the mitochondria has been shown in cardiomyocytes [58]. Mitochondria are the powerhouses of the living cells and produce energy primarily via oxidative phosphorylation. Also, mitochondria are the major source of ROS in the cardiovascular system [51, 58] (Fig. 2, Table 2). The aconitase of the Kreb's cycle in the mitochondria matrix produces NADH and FADH2 which are oxidized for ATP production in the electron transport chain (ETC) located in the inner membrane of the mitochondria. The ETC mediates electron flow through series of electron carriers including complexes I, II, III and IV as well as ubiquinone and

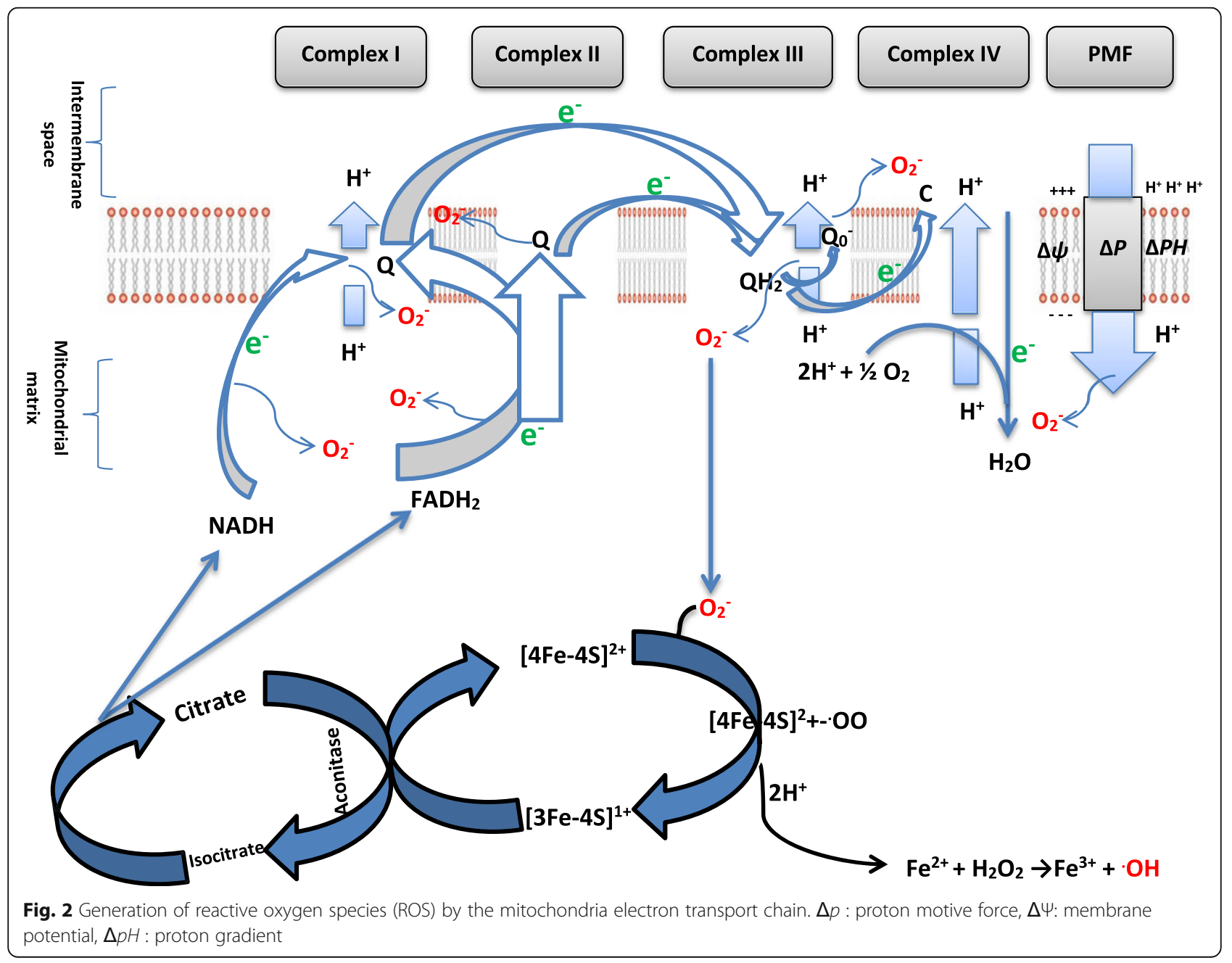


Table 2 Enzymes and inhibitors of the electron transport chain (ETC)

\begin{tabular}{lll}
\hline Complex & Enzymes & Inhibitors \\
\hline Complex I & NADH-ubiquinone oxidoreductase & Rotenone, Amobarbital (Amytal), Demerol, Piericidin, \\
Complex II & Succinate- ubiquinone oxidoreductase & Thenoyltrifluoroacetne (TTFA), Malonate oxaloacetate, Diazoxide \\
Complex III & Ubiquinone cytochrome-c oxidoreductase & Antimycin A, Myxothiazol, Stigmatellin \\
Complex IV & Cytochrome-c oxidase & Cyanide, Carbon monoxide, Azide, Hydrogen sulphide \\
Complex V & ATP synthase & Oligomycin A, Diyclo hexyl carbo dimide (DCCD) \\
\hline
\end{tabular}

cytochrome c. As electron flows through the ETC, protons are translocated from the mitochondria matrix to the mitochondria inter-membrane space, thus creating an electrochemical potential gradient across the inner membrane. Generation of superoxide anion radicals in the mitochondria is mainly by electron leakage from the chain. Under physiological conditions, the oxygen tension in the mitochondria is low in state 4 respiration and oxygen consumption by the chain does not meet the demand of oxidative phosphorylation. Hence, a decrease in the rate of mitochondrial oxidative phosphorylation increases electron leakage from the ETC and conversely generation of superoxide anion radical.

$\mathrm{XO}$ generates $\mathrm{O}_{2}{ }^{-}$as a secondary metabolite of purine catabolism. NOS uncoupling and subsequent $\mathrm{O}_{2}{ }^{-}$generation have been linked with vascular endothelial dysfunction. Although, NOS primarily produces nitric oxide (NO), it may generate $\mathrm{O}_{2}{ }^{-}$if it becomes uncoupled. Uncoupling of NOS is commonly seen when its co-factor, tetrahydrobiopterin $\left(\mathrm{BH}_{4}\right)$, or its substrate, L-arginine, is deficient [59]. NADPH oxidases may also contribute to the generation of ROS by degrading $\mathrm{BH}_{4}$ via oxidation, thus causing NOS uncoupling [60], or activating xanthine oxidase [61].

Oxidative stress triggers apoptosis via several pathways activating enzymes involved in pro-apoptotic signalings, such as JNK, p38, ASK-1, and CaMKII [62] with resultant release of cytochrome-c. Though the excessive generation of ROS by NOX is deleterious, at minimal to moderate levels, $\mathrm{H}_{2} \mathrm{O}_{2}$ and $\mathrm{O}_{2}{ }^{-}$produced by NOX, act as signalling molecules, thus mediating physiological responses [63].

\section{ROS and the vasculature}

ROS influence pathological and physiological processes in the vasculature. Predisposing factors to CMD like DM, obesity, hypertension, dyslipidaemia, and ageing result in vascular dysfunction partly through oxidative stress [64]. ROS is essential for the growth, proliferation, and migration of endothelial cells (ECs) and smooth muscle cells (SMCs), as well as angiogenesis, apoptosis of EC and SMC, vascular tone, host defence, and genomic stability [65]. OS does not only induce macromolecular damage, it also alters vascular redox-dependent signaling pathways [66]. ROS target signaling pathways such as mitogen activated protein kinases (MAPKs) which include extracellular signal-regulated kinases (ERK1/ 2), p38 and c-Jun $\mathrm{N}$-terminal kinases [67]. It also targets serine/threonine kinase Akt/protein kinase B, epidermal growth factors (EGF), and platelet-derived growth factors (PDGF). In oxidative stress, ROS triggers endothelial dysfunction via disruption of vasoprotective NO signaling [68].

$\mathrm{NO}$ is a vasodilator that acts via cGMP which is produced by SMCs. NO inhibits platelet adhesion and aggregation, thus acting as an anti-atherogenic factor. It also prevents leukocyte-endothelial interactions and $\mathrm{MC}$ proliferation [69]. $\mathrm{O}_{2}{ }^{-}$rapidly reacts with $\mathrm{NO}$ to produce peroxynitrite $\left(\mathrm{ONOO}^{-}\right)$, which is also a potent oxidant [70]. $\mathrm{ONOO}^{-}$formation occurs more rapidly than superoxide dismutase (SOD)-dependent dismutation of $\mathrm{O}_{2}{ }^{-}$ [71]. The formed $\mathrm{ONOO}^{-}$induces $\mathrm{BH}_{4}$ oxidation with resultant eNOS uncoupling [72] thus converting eNOS into a pro-oxidant [73]. Hence, $\mathrm{ONOO}^{-}$formation depletes NO concentration and also induces eNOS uncoupling.

ROS also triggers the structure of the inflammasome, IL- $1 \beta$, and IL- 8 via the activation of caspase-1 [74]. This pathway is vital in atherosclerosis.

As highlighted previously, NADPH oxidase, $\mathrm{XO}$, and uncoupled eNOS, including lipoxygenase, cyclooxygenase, and cytochrome $\mathrm{P} 450$ monooxygenase are key enzymes that generate ROS in the cells as well as in the vascular wall. ROS are involved in the structural modification of the vascular wall thickness and lumen diameter [75]. This is consequent to the passive adaptation to chronic changes in hemodynamics and neuro-humoral factors such as angiotensin II and ROS [75]. This vascular remodelling could be inward eutrophic or hypertrophic, and play a role in the development of hypertension. The inward eutrophic remodelling involves reduction in the size of the lumen, media thickening, improved media to lumen ratio, and little alteration in the cross-sectional area of the media [76], while the hypertrophic remodelling involves an enhancement in the cross-sectional area of the vascular wall, size of the cell and accumulation of ECM proteins like collagen and fibronectin [77]. 


\section{Vascular ROS scavenging}

Mitochondria as the primary source of ROS CMD is accompanied by an imbalance in vascular ROS generation and scavenging. The primary defense against vascular ROS is discussed below.

Superoxide dismutase In humans, SOD1, SOD2, and SOD3 are the three known SOD isoforms. SOD1 (copper, zinc $[\mathrm{Cu}-\mathrm{Zn}]-\mathrm{SOD})$ is located in the cytoplasm and mitochondrial intermembrane space, SOD2 (Mn-SOD) is located in the mitochondrial matrix, while SOD3 (extracellular [EC]-SOD) is located in the extracellular space [78]. SOD dismutates $\mathrm{O}_{2}^{-}$to $\mathrm{H}_{2} \mathrm{O}_{2}$ and oxygen, hence prevents the inactivation of NO. However, high concentrations of the secondary metabolites of the dismutation may cross cellular membranes to generate proatherogenic molecules [78-81]. The effect of SOD is dose-dependent.

Catalase Catalase decomposes $\mathrm{H}_{2} \mathrm{O}_{2}$ to oxygen and water. Up-regulation of this enzymatic antioxidant inhibits atherosclerosis [80] and impairs angiotensin IImediated aortic wall hypertrophy [82].

Glutathione peroxidase Glutathione peroxidase (GPx) catalyzes the reduction of $\mathrm{H}_{2} \mathrm{O}_{2}$ to water, and lipid peroxides to their alcohols $[83,84]$. Although there are 8 isoforms of GPx, GPx1 and GPx4 seem to be the most studied. GPx1 is found in many cell types, and its deficiency has been linked with atherosclerosis $[85,86]$. On the other hand, GPx4 is expressed in the endoplasmic reticulum (ER), cytoplasm, mitochondria, and plasma membrane. GPx4 prevents atherogenesis by impairing lipid peroxidation and the sensitivity of vascular cell to oxidized lipids [87].

Paraoxonase Paraoxonases (PON) include PON-1, PON-2, and PON-3. PON exhibit anti-atherogenic properties, possibly via inhibition of oxidative stress [88]. PON-1 is primarily secreted by the liver [89]. PON-1 prevents the peroxidation of HDL and LDL, breaks down cholesteryl esters and lipoproteins seen in oxidized lipoproteins, and also prevents OS, inflammation, and monocyte attraction via blunting myeloperoxidaseinduced ROS generation. PON-2, which is expressed in the ER and mitochondrial membranes, exerts its effects on the vascular cells $[90,91]$. PON-3, which is located in the serum and cells [92], prevents atherogenesis [93, 94].

Heme oxygenase $\mathrm{HO}$ catalyzes degradation of heme to carbon monoxide (CO), biliverdin, and free ferrous iron [95]. $\mathrm{HO}$ exists in three isoforms; the inducible (HO-1), constitutive (HO-2), an enzymatically inactive (HO-3) forms [95]. OS, hypoxia, and some cytokines stimulate the upregulation of the inducible isoform, which are key in impairing vascular remodelling and atherosclerosis [95]. Although at moderate concentrations, the $\mathrm{CO}$ produced by $\mathrm{HO}$ has anti-inflammatory, antiproliferative, and vasodilatory activities, it is toxic at a very high concentration [96]. Biliverdin is a pigment that scavenges radicals and also blunts the effect of NOX [97].

Thioredoxin Thioredoxin (Trx) is an enzymatic antioxidant that is located in the ECs, SMCs, and fibroblasts [98]. It is vasoprotective and reverses agerelated arterial stiffness and raised blood pressure via enhancement of vascular redox and restoration of the function of eNOS [98].

Non-enzymatic antioxidants Bilirubin, uric acid, glutathione, exogenous substances like vitamins (mainly vitamins $\mathrm{C}$ and $\mathrm{E}$ ) and polyphenols, contribute to the antioxidant defence system [99]. Bilirubin and uric acid scavenge extracellular radicals, while glutathione modifies the intracellular redox state [99]. Vitamin C (ascorbic acid) scavenges several oxidative/nitrogen species, stabilizes $\mathrm{BH} 4$ and eNOs, and restores vitamin $\mathrm{E}$ from its radical state (tocopheroxyl radical) [100]. $\alpha$ tocopherol is the principal member of vitamin $E$ with antioxidant property. Sources of polyphenolic antioxidants include food such as vegetables and cocoa and beverages. Polyphenolics impair NADPH oxidases activities [101, 102].

Micronutrients like selenium, copper, zinc, iron, and calcium also contribute to the antioxidant buffering capacity. Selenium protects against oxidative DNA damage. It acts via selenoenzymes-mediated mechanism such as GPx [103]. As selenium serves as a co-factor of GPx, copper and zinc are co-factors of SOD, while the iron is a co-factor of catalase. Thus, these elements influence the activities of the respective enzymatic antioxidants. Note worthily, iron and copper may act as pro-oxidants by catalyzing the production of hydroxyl $(\mathrm{OH})$ radicals from $\mathrm{O}_{2}{ }^{-}$and $\mathrm{H}_{2} \mathrm{O}_{2}[104,105]$. Although calcium is critical in excitation-contraction coupling, it also plays vital physiological roles like the regulation of gene expression and cellular energetics [106-110].

\section{Biomarkers of oxidative stress}

Oxidative stress has been shown to be a key player in various diseases including cardiometabolic disorders. A wide range of methods have been developed and employed to measure the nature and extent of oxidative stress ranging from oxidation of lipids to free amino acids and proteins, and DNA. Although diverse oxidative stress biomarkers are available as predictors of various diseases, the specificity of each seems to be yet 
established. Available biomarkers of oxidative stress have been summarized in Table 3.

\section{Oxidative stress and CMD Oxidative stress and obesity}

Emerging evidences implicating OS as the soil for the initiation and progression of dyslipidaemia, obesity, IR, $\mathrm{DM}$, hypertension and atherosclerosis exit. Obesity is the primary causal component of CMD [111-114] (Fig. 3). Consumption of an energy-dense meal is linked to a significant increase in the concentrations of 4-hydroxyl 2-nonenal (HNE) [116], thus is essential in the incidence of obesity. Notably, Johnson et al. [117] have reported a reduced HNE level of HNE in obese individuals on calorie restriction. This underscores the essence of OS via HNE in incident obesity. ROS generation rises in parallel with fat adipocyte fat accumulation, and the increase in the level of FFAs also stimulates adipocyte ROS generation via NADPH oxidase activation and decline in enzymatic antioxidant expression [115]. In the presence of OS in adipocytes, anti-inflammatory adiponectin level

Table 3 Biomarkers of oxidative stress

\begin{tabular}{|c|c|}
\hline \multicolumn{2}{|c|}{ Markers of oxidative stress } \\
\hline Lipid oxidation & $\begin{array}{l}\text { Malondialdehyde (MDA), 4-hydroxy-2-nonenal } \\
\text { (4-HNE), F2-isoprostanes, isolevuglandins, acro- } \\
\text { lein, crotonaldehyde, and methylglyoxal. }\end{array}$ \\
\hline $\begin{array}{l}\text { Protein/amino acid } \\
\text { oxidation }\end{array}$ & $\begin{array}{l}\text { Protein carbonyls, advanced glycation } \\
\text { endproducts (AGEs), advanced lipoxigenation } \\
\text { end products (ALES), advanced oxidation } \\
\text { protein products (AOPP), 3-nitrotyrosine, } \\
\text { ischemia-modified albumin (IMA), oxidized low } \\
\text { density lipoprotein (oxLDL) }\end{array}$ \\
\hline DNA oxidation & $\begin{array}{l}\text { 8-oxo-2' - deoxyguanosine (8-oxo-dG; 8OHdG), } \\
\text { 5-chlorocytosine, 5-chlorouracil, }\end{array}$ \\
\hline \multicolumn{2}{|c|}{ Markers of ROS generation } \\
\hline Enzymatic & $\begin{array}{l}\text { Xanthine oxidase (XO), myeloperoxidase } \\
\text { (MPO), nicotinamide adenine dinucleotide } \\
\text { phosphate oxidase (NOX), nitric oxide } \\
\text { synthase (NOS) }\end{array}$ \\
\hline Non-enzymatic & Uric acid \\
\hline $\begin{array}{l}\text { ROS-regulated } \\
\text { transcription factors }\end{array}$ & $\begin{array}{l}\text { Nuclear factor kappa-light-chain-enhancer of } \\
\text { activated B cells (NF-kB) }\end{array}$ \\
\hline \multicolumn{2}{|c|}{ Markers of antioxidant defense } \\
\hline Enzymatic & $\begin{array}{l}\text { Superoxide dismutase (SOD), catalase (CAT), } \\
\text { glutathione peroxidase (GPx), glutathione } \\
\text { reductase (GR), glutathione S-transferase (GST), } \\
\text { glucose -6- phosphate dehydrogenase (G6PD), } \\
\text { Protein thiol-disulfide oxidoreductases [thiore- } \\
\text { doxin (Trx) and peroxiredoxins (Prxs)]. }\end{array}$ \\
\hline Non-enzymatic & $\begin{array}{l}\text { Ascorbic acid, a-tocopherol, } \beta \text {-carotene, poly- } \\
\text { phenols, bilirubin, albumin, ceruloplasmin, fer- } \\
\text { ritin, glutathione (GSH). }\end{array}$ \\
\hline $\begin{array}{l}\text { ROS-regulated } \\
\text { transcription factors }\end{array}$ & $\begin{array}{l}\text { Nuclear factor (erythroid-derived 2)-like } 2 \text { (Nrf- } \\
\text { 2) }\end{array}$ \\
\hline Others & Asymmetric dimethyl L-arginine (ADMA) \\
\hline
\end{tabular}

falls [118, 119], while pro-inflammatory adipocytokines concentration rises $[115,120,121]$. Dysregulation of adipocytokines is vital in the development of obesityassociated metabolic disorder. Raised adipocyte generation of PAI-1, MCP-1, and TNF- $\alpha$ is important in the pathogenesis of thrombosis [122], and IR [123, 124]. Since adiponectin increases cellular sensitivity to insulin [37, 125-127] and also possesses anti-atherogenic effects [128-130], a marked reduction in the circulatory concentrations of adiponectin results in IR and atherosclerosis via systemic inflammation [115]. HNE up-regulates the expression of inducible cyclooxygenase (COX-2) and PAI-1 [131] and down-regulates the expression of adiponectin $[119,132]$. Dysregulation of adipocytes results in systemic inflammation; this as well as increased adipocyte ROS generation promotes endothelial dysfunction. This is key in the development of IR, DM and atherosclerosis. Interestingly, renin-angiotensin-aldosterone system (RAAS) which plays an important role in blood pressure and volume regulation, has also been demonstrated to trigger adipocyte ROS generation [133].

\section{Oxidative stress and IR/diabetes}

Following systemic inflammation, oxidative damage to the endothelial cells causes impaired glucose uptake and utilization by hepatocytes and skeletal myocytes. Activation of NOX via RAAS increases endothelial ROS generation $[134,135]$. This is dependent on angiotensin II type-1 and mineralocorticoid receptors [136]. This cascade of events continues and causes a transition from IR to DM type II [137]. Oxidative injury to the endothelium reduces the circulatory level of NO due to the decline in its synthesis by uncoupling eNOS via ROS-induced oxidation and depletion of BH4 [138, 139]. Increased generation of $\mathrm{ONOO}^{-}$via coupling of $\mathrm{NO}$ to superoxide also contributes to NO depletion [140]. The generated $\mathrm{ONOO}^{-}$is very reactive and leads to endothelial cell death $[140,141]$ which also impairs endothelial NO generation. It is a known fact that eNOS-derived NO is essential in angiogenesis by enhancing vascular endothelial growth factors and up-regulating the recruitment of endothelial progenitor cells from the bone marrow [142, 143]. Hence ROS-induced decline in circulatory NO secondary to endothelial dysfunction impairs the growth of the capillary network and blood flow regulation and subsequent diminution of microcirculation in metabolically active tissues and dysregulations of glucose and dyslipidaemia.

Studies have implicated OS in IR and DM through insulin signaling, insulin-induced GLUT 4 translocation and glucose uptake via insulin receptor substrate (IRS) phosphorylation, MARK activation and ER stress. Activation of serine/threonine kinase cascade stimulates serine phosphorylation of IRS that in turn impairs 


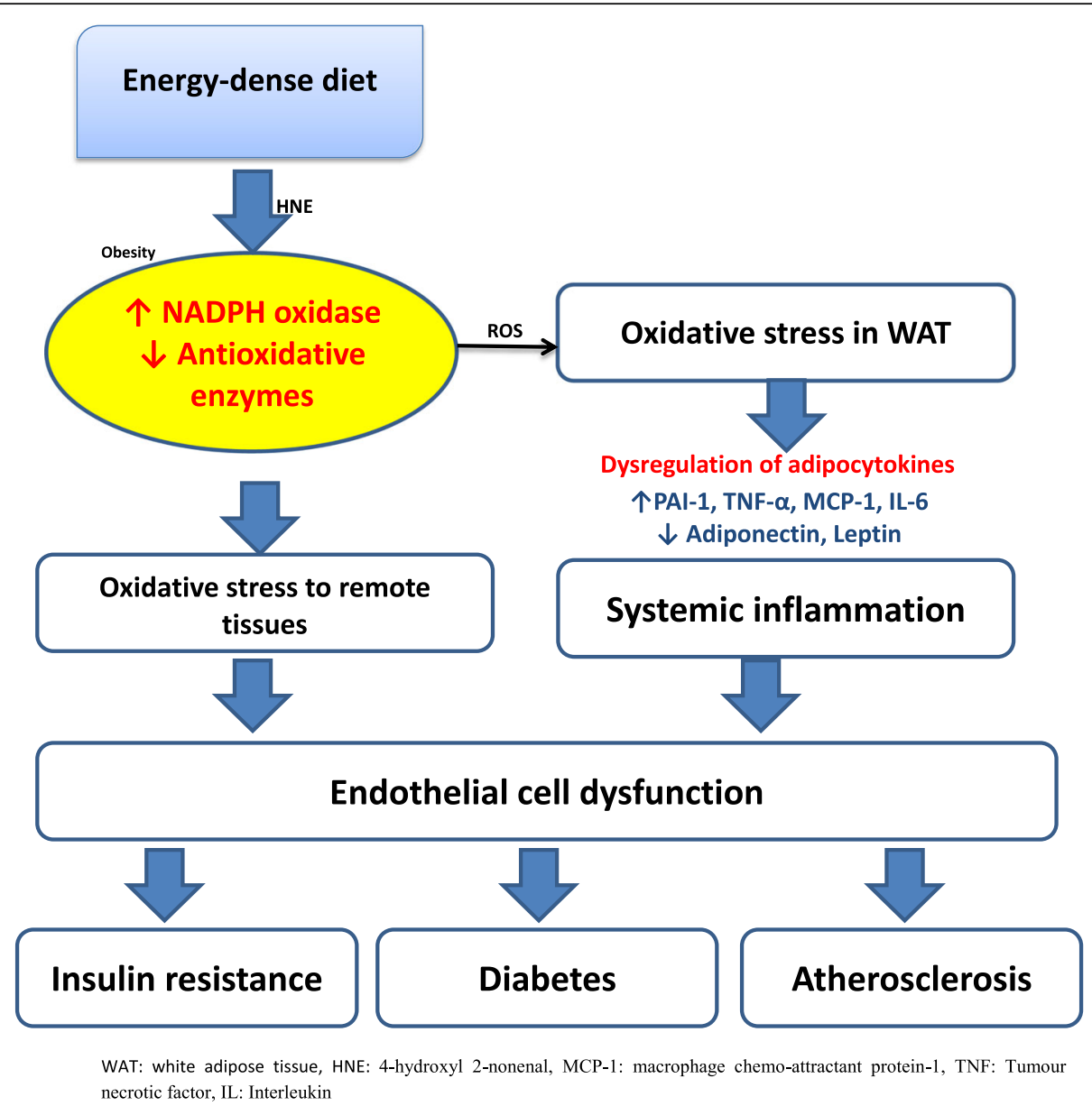

Fig. 3 The role of oxidative stress in the development of obesity and cardiometabolic disorders. This illustration is a modification of the working model illustrating how increased ROS production in accumulated fat contributes to metabolic syndrome by Furukawa et al. [115]

tyrosine phosphorylation thus possibly enhancing IRS degradation [144], resulting to alteration of glucose uptake signalling pathways by GLUT4 via IRS-1 and phosphatidylinositol 3-kinase (PI3K)/Akt [137]. Impairment of glucose uptake through this pathway exerts a further negative effect on IR. Adipocytes, which act as glucose sensors [145], senses impaired GLUT4-mediated glucose uptake and release adipocytokines (such as retinolbinding protein 4, RBP 4) to prevent glucose uptake by skeletal muscle and improve hepatic glucose output through insulin signalling blockade [146]. This sums up to raised plasma level of glucose. Hence OS mediates the development of IR and DM type II via downregulation of circulatory NO bioavailability and GLUT 4 expression in adipocytes (Fig. 4).

\section{Oxidative stress and hypertension}

The role of NO in the pathophysiology of hypertension has well clearly described. NO enhances angiogenesis and blood supply, thus regulates blood pressure. NO may react with $\mathrm{O}^{-}$to increase the generation of $\mathrm{ONOO}^{-}$, which break down to form hydroxyl radical [147, 148]. The generated $\mathrm{ONOO}^{-}$causes eNOS uncoupling, iNOS uncoupling, and $\mathrm{BH}_{4}$ depletion [137]. Under physiological conditions, electrons are transferred from a heme group in the oxygenase domain to L-arginine by eNOS. This leads to the generation of L-citrulline and $\mathrm{NO}$ [149]. However, when there is a depletion of NO, may be due to depletion of $\mathrm{L}$-arginine, a substrate of $\mathrm{NO}$, or $\mathrm{BH}_{4}$, a co-factor in NO production, eNOS switches to an uncoupled state from a coupled state. This leads to the reduction of oxygen by electrons from the heme group with subsequent production of superoxide radical $\left(\mathrm{O}_{2}{ }^{-}\right)$[150]. This radical reacts with NO to further deplete NO, leading to endothelial dysfunction and rise peripheral resistance, thus causing a sustained rise in blood pressure. Depletion of L-arginine is associated with exaggerated arginase II activity. iNOS expression is also up-regulated in endothelial dysfunction [137]. Although iNOS generates NO, due to oxidative stressinduced $\mathrm{BH}_{4}$ depletion and iNOS uncoupling, iNOS uncoupling enhances oxidative stress. Also, it leads to a 


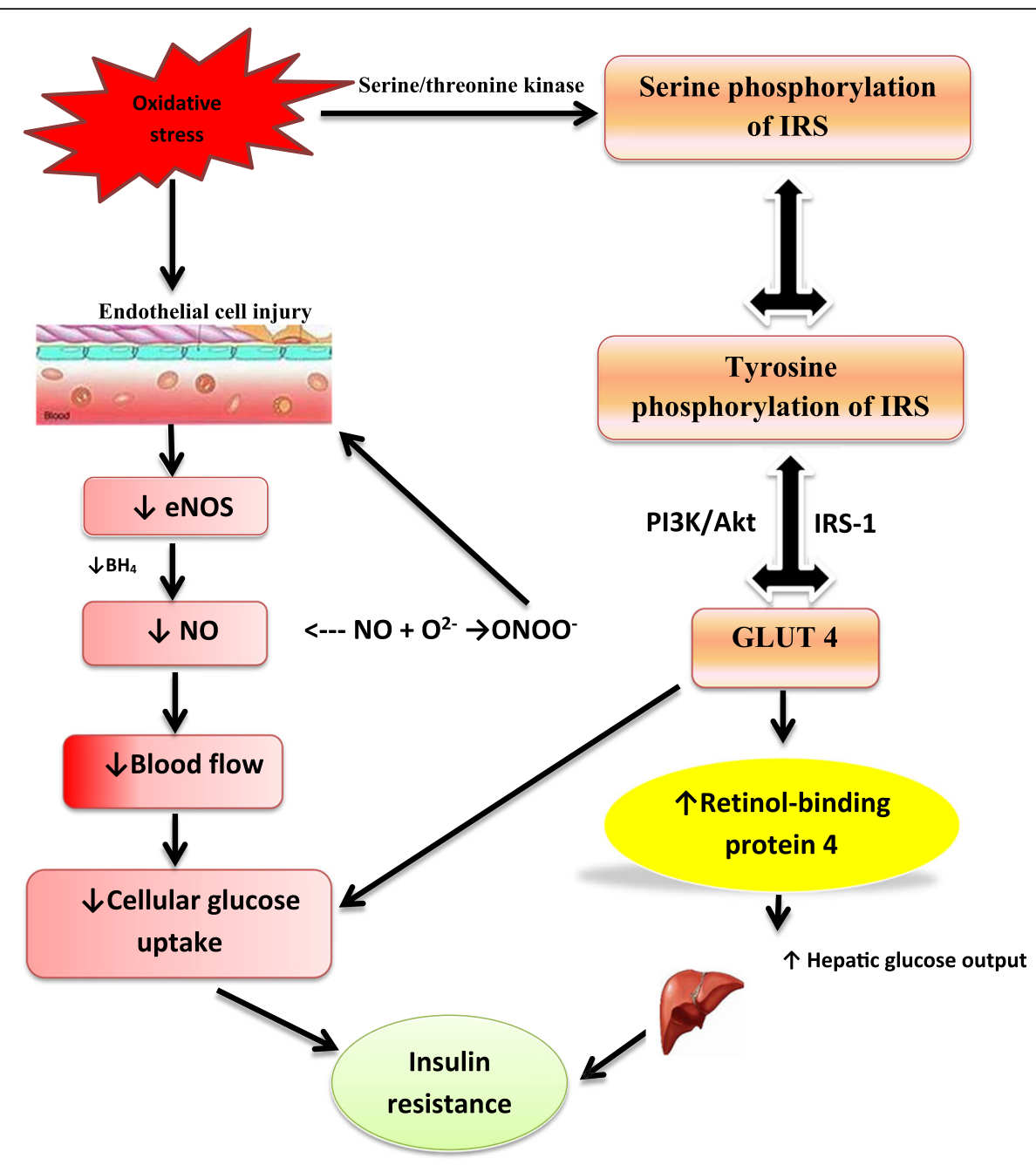

IRS: insulin receptor substrate, $\mathrm{PI} 3 \mathrm{~K}$ : phosphatidylinositol 3-kinase, $\mathrm{BH}_{4}$ : tetrahydrobiopterin, eNOS: endothelial nitric oxide synthase

Fig. 4 The role of oxidative stress in the pathogenesis of insulin resistance/type II diabetes. This illustration is a modification of the mechanism illustrating the role of oxidative stress to adipocytes in insulin resistance by Otani $\mathrm{H}$ [137].

vicious cycle of endothelial dysfunction and persistent rise in blood pressure (Fig. 5). In addition, endogenous eNOS inhibitor, asymmetric dimethyl-L-arginine (ADMA) may contribute to eNOS uncoupling. Oxidative stress has been demonstrated to enhance the activity of protein arginine N-methyltransferase (PRMT) and reduce the activity of dimethylarginine dimethylaminohydrolase (DDAH), an ADMA-degrading enzyme, thus resulting in a rise in ADMA concentrations [69, 151, 152]. The rise in ADMA levels may inhibit NO synthesis by eNOS or even lead to eNOS uncoupling $[69,151]$. Note worthily, $\mathrm{BH}_{4}$ depletion-driven eNOS uncoupling may rather be secondary to the oxidation of zincthiolate cluster of eNOS. Exposure of isolated eNOS to $\mathrm{ONOO}^{-}$causes disruption of the zinc-thiolate cluster of the enzyme [153]. Since the Cys99 in this cluster is essential for $\mathrm{BH}_{4}$ binding, oxidation of this cluster will disrupt the $\mathrm{BH}_{4}$ binding site of the enzyme; an state similar to depletion of $\mathrm{BH}_{4}$.

Local RAAS activation plays an integral role in the complex cascades that contribute to endothelial dysfunction. Studies have shown that the accumulation of visceral fat and raised OS and inflammatory response in adipose tissue enhance the release of components of adipose RAAS. Animal studies have demonstrated upregulation of angiotensinogen in fatty tissue in obesity. This is strongly linked with hypertension [154]. Angiotensinogen converts angiotensin I to angiotensin II, which exerts its effects via angiotensin II type 1 receptor $\left(\mathrm{AT}_{1} \mathrm{R}\right)$ [149]. In the zona glomerulosa of the adrenal cortex, activation of $\mathrm{AT}_{1} \mathrm{R}$ triggers the release of mineralocorticoids [149], which elevate blood pressure 


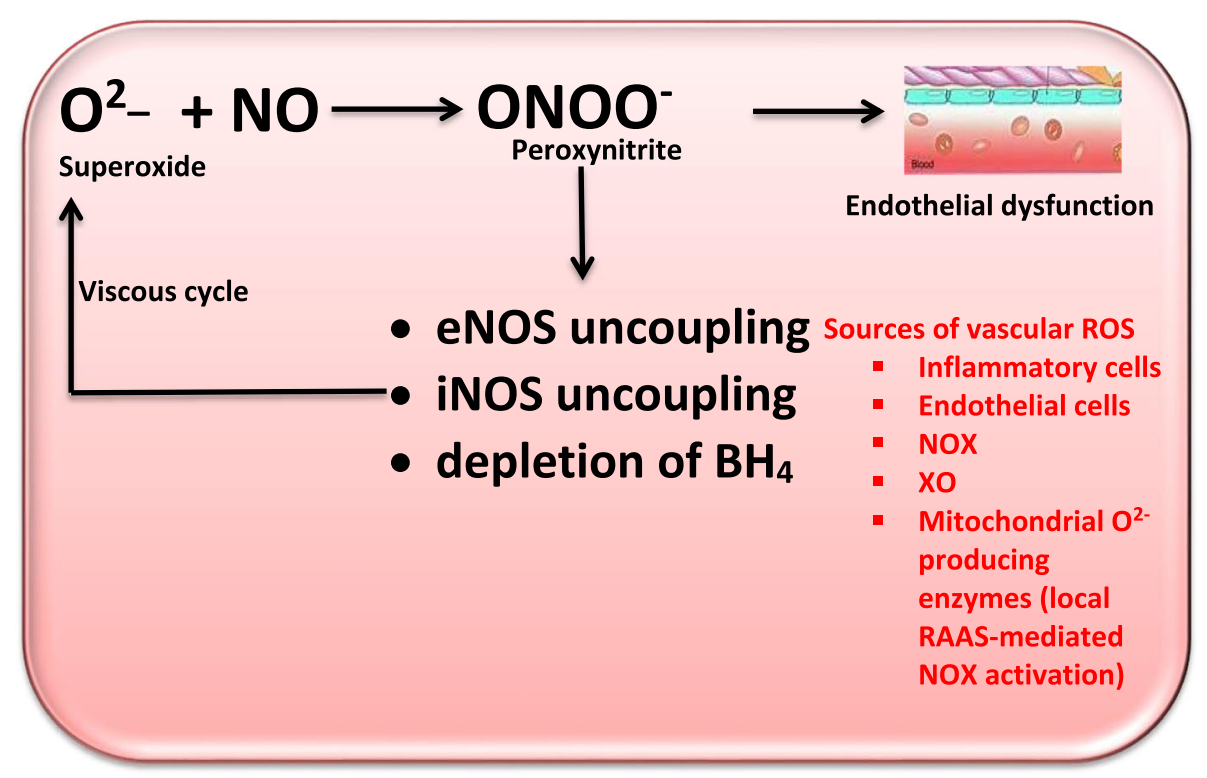

Fig. 5 The role of oxidative stress in the pathogenesis of hypertension. $\mathrm{XO}$ : xanthine oxidase, NOX: nicotinamide adenine dinucleotide phosphate oxidase, eNOS: endothelial nitric oxide synthase, OxLDL: Oxidized LDL, ROS: reactive oxygen species, PDGF: Platelet-derived growth factor, SMC: smooth muscle cells, MF: Myofibrils

primarily via stimulation of sodium reabsorption and expansion of plasma volume, and secondarily via nongenomic mineralocorticoid receptor (MR)-mediated actions [155]. In non-adrenal tissues, activation of $\mathrm{AT}_{1} \mathrm{R}$ triggers ROS generation with resultant impairment of insulin signaling, as well as proliferative and inflammatory responses [156]. This penultimately leads to endothelial dysfunction and hypertension. It is worthy to note that mineralocorticoids such as aldosterone and deoxycorticosterone acetate have been reported to activate NADP $\mathrm{H}$, trigger oxidative stress and release superoxides [157, 158].

$\mathrm{XO}$ is a hypoxia-inducible enzyme, which is found in vascular smooth muscle cells (VSMCs) and vascular endothelial cells. XO catalyzes superoxide production [149]. Mervaala and colleagues [159] documented that rodents with over-expressed human renin and angiotensinogen genes have raised XO activity with endothelial dysfunction and hypertension. Experimental studies have also demonstrated increased renal $\mathrm{XO}$ activity in salt-fed spontaneously hypertensive rats [160].

Membrane-bound vascular-derived NOX enzymatic complex can be activated by angiotensin II and aldosterone even at low concentrations [161]. Activation of this system is a major source of ROS, which leads to NO depletion and endothelial dysfunction. Mounting number of studies has implicated the crosstalk between NOX and mitochondria with incident eNOS dysregulation/uncoupling and endothelial dysfunction. It has been established that Ang II stimulates mitochondrial ROS (mtROS) formation and opening of the mitochondrial permeability transition pore (mPTP) with resultant leakage of the generated mtROS to the cytosol [162, 163]. This activates the p38 MAPK and JNK signaling with subsequent activation of NOX $[162,163]$. Also, NOX could be activated through cSrc-dependent phosphorylation of p47phox, which is triggered by Ang II. Ang IIdependent NOX causes mitochondrial dysfunction with consequent mtROS formation [164, 165]. This cascade of events leads to a robust accumulation of mtROS formation with cardiovascular implications. mtROS-driven phagocytic NOX activation triggers immune cell infiltration and aggravates Ang II-mediated eNOS uncoupling [166], reduced circulatory $\mathrm{NO}$ and endothelial dysfunction.

Although enzymatic superoxide dismutase scavenges the superoxides that are produced in the mitochondria during oxidative phosphorylation, this mechanism may be overwhelmed when ROS generation is exaggerated. This leads to mitochondrial DNA damage and endothelial injury [167].

\section{Oxidative stress and atherosclerosis}

Atherosclerosis is the common clinical disorder that results from obesity, IR and DM, and hypertension (Fig. 6). It begins with the formation of atheromatous plaque, which is triggered by endothelial ROS generation and accumulation of LDL in the intima. LDL consists of an $A$ poB protein molecule, triglycerol, cholesterol and its esters, phospholipids, and vitamin E [168]. The presence of TG enhances the influx and accumulation of LDL in the tunica intima, where it is oxidized by ROS, and 
picked up by macrophages via scavenger receptor (SR) CD36 to produce foam cells [169-171]. Other SRs such as SR-AI, SR-AII, MARCO, and SRCL (class A), SR-BI (class B), CD68 (Class D), LOX-1 (class E), SREC-1 (Class F), and SR-PSOX/CXCL16 (Class G) have been reported [172].

Oxidized LDL (OxLDL) is cytotoxic to atherosclerosisrelated cells such as T-cells, macrophages, ECs, and SMCs [173] via OxLDL-derived lipid peroxides and hydroperoxides [174]. High concentrations of OxLDL activates caspase 3 in a Fas-independent manner, thus causing apoptosis with characteristic DNA fragmentation [168]; although, caspases 6, 8 and 9 may also be involved. Besides, OxLDL simultaneously triggers necrosis via ROS [168]. Although OxLDL suppresses nuclear factor-kappa B (NF-kB) in long-term, it activates it in short-term in ECs, SMCs, and macrophages [175-177]. OxLDL-induced NF-kB activation is via LOX-1. Binding of OxLDL to LOX-1 promotes the production of $\mathrm{O}^{-}$and $\mathrm{H}_{2} \mathrm{O}_{2}$, as well as activation of NF-kB via p38 MAP kinase//P13K/ERK1/2 signaling pathway [178, 179], thus eliciting an inflammation in the endothelial cells. NF-kB regulates the expression of MCP-1, P-selectin, E-selectin, ICAM-1, and VCAM-1 [180].
Recruitment of monocyte-macrophage into the intima is regulated by adhesion molecules, integrins, selectins, and chemokines such as monocyte chemo-attractant protein-1 (MCP-1) [181, 182]. ROS does not just oxidize OxLDL; they also up-regulate MCP-1 and other molecules that are responsible for monocyte-macrophage recruitment. Although, SMCs and ECs synthesize MCP-1, SMCs also moves to the tunica intima from the tunica media, where they differentiate into myofibroblasts and increase in the presence of PDGF $[183,184]$ and insulin via ROS-dependent phosphorylation of serine residues of IRS-1 $[185,186]$. These myofibroblasts are responsible for collagen synthesis, which causes intima thickening.

Enhanced inflammatory response and OS promote apoptosis of the foam cells and necrotic lipid core formation [187, 188]. The necrotic lipid core is covered with a collagen fibre-enriched fibrous cup which is lyzed by activation of matrix metalloproteinases (MMP) in the presence of ROS [189, 190] generating an advanced atheromatous plaque called unstable plaque. This narrows the lumen of the artery and raises the intraluminal pressure.

It has been established that coronary artery disease progresses faster in diabetic patients. There are

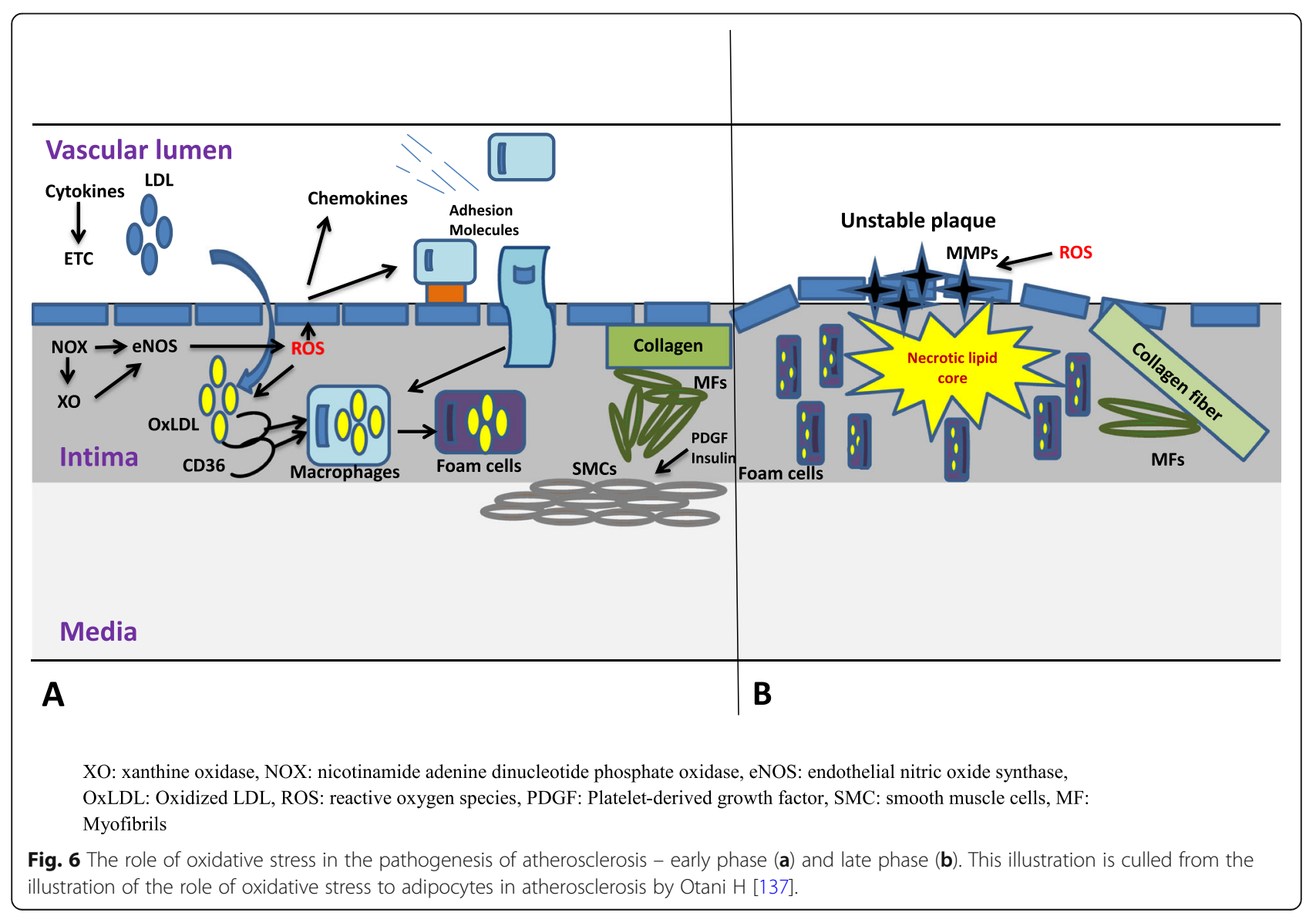


mounting evidence that suggestive that adiposity and impaired glycaemia promote the development of ischaemic heart disease (IHD) even in non-diabetic individual [191, 192]. Although insulin-treated diabetes has been shown to be an independent predictor of late and repeat coronary revascularization [193], study of Komatsu et al. [194] revealed that IR in the general population treated with percutaneous coronary intervention (PCI) enhanced restenosis due to continuous neointimal growth after the first generation drug eluting stent (DES) implantation. Sasso and his colleagues [192] in a prospective longitudinal observational study demonstrated the role of IR and cytokines in the incident of IHD in normoglycaemic subjects. Findings of their study showed that adiponectin levels were independently associated with restenosis; and HOMA-IR and adiponectin were independently associated with de novo IHD and overall new PCI.

\section{Cardiac metabolic memory}

Even when glucose level has been restored, chronic rise in glucose concentration as seen in DM stimulates metabolic alterations that modify tissue homeostasis. This is called metabolic memory [195]. Epigenetics is essential in establishing cardiac metabolic memory. Chronic epigenetic effects like histone and DNA methylations are quite stable and may be inherited as a memory by offspring cells [196]. In addition, maternal nutrition as well as in utero exposure may trigger developmental programming which may also be transferred to progenies, thus triggering disorders like CMD [197]. Hyperglycemia may trigger long-term inflammatory and oxidative stress pathways. This is accompanied by resultant persistent or possibly permanent modifications [198]. Experimental study demonstrates hyperglycemia-dependent ROS as a primary trigger of endothelial glycemic memory [199]. Studies have revealed that hyperglycemia stimulates a reversible increase in the concentrations of IL6 and decline in histone- 3 methylation at the IL-6 promoter in cardiomyocytes [200]. This infers that the raised inflammatory gene expression in cardiomyocytes observed in hyperglycemia is secondary to impaired repressive epigenetic histone modifications [200]. It is not unlikely that hyperglycemia-stimulated mitochondrial dysfunction and apoptosis account for cardiac metabolic memory [200]. Also, hyperglycemia triggers developmental control of insulin-like growth factor-1 (IGF-1) receptor in cardiac muscle cells [201]. Human studies have revealed that a rise in adipose tissue accumulation in obesity is linked to enhanced methylation at the hypoxia-inducible factor 3A (HIF3A) locus in blood cells and adipose tissue, but not in the skin [202]. Metabolic intermediates from catabolism of macromolecules serve as cofactors for chromatin-modifying enzymes [203-214].

\section{Conclusion and future perspectives}

Oxidative stress, through a complex cascade, is essential in the development of CMD. Increasing evidence has demonstrated that ROS via various pathways triggers systemic inflammation and endothelial cell dysfunction through several mechanisms, such as mitochondrial dysfunction and uncoupling, raised FAO, up-regulation of NOX activity, impaired antioxidant capacity, and cardiac metabolic memory. Although more studies aimed at demonstrating other associated pathogenesis of CMD is important, a good understanding of the link between oxidative stress and CMD opens new therapeutic horizons in the management of CMD by targeting one or more specific pathways in the pathophysiology.

\section{Abbreviations \\ CMD: CMD; HDL: high-density lipoprotein; LDL: low-density lipoprotein; OxLDL: Oxidized LDL; TG: triglycerides; VLDL: very-low-density lipoprotein; ATP III: Adult Treatment Panel III; IDF: International Diabetes Foundation; (NCEP): National Cholesterol Education Program; TNF-a: tumour necrosis factor-alpha; IL: interleukin; MCP-1: macrophage chemo-attractant protein 1; ROS: reactive oxygen species; RNS: reactive nitrogen species; XO: xanthine oxidase; eNOS: uncoupled endothelial nitric oxide synthase; HO: heme oxygenase; XDH: xanthine dehydrogenase; Ang II: angiotensin II; GDP: guanosine diphosphate; PI (3) P: phosphatidylinositol 3-phosphate; $\mathrm{BH}_{4}$ : tetrahydrobiopterin; ECs: endothelial cells; SMCs: smooth muscle cells; GTP: guanosine-5'-triphosphate; MAPKs: mitogen-activated protein kinases; ERK: extracellular signal-regulated kinases; NO: nitric oxide; NOX: nicotinamide adenine dinucleotide phosphate oxidase; $\mathrm{O}_{2}$ : superoxide anion radicals; $\mathrm{ONOO}$ : peroxynitrite; ECM: extracellular matrix; HIF: hypoxia- inducible factor; SOD: superoxide dismutase; $\mathrm{H}_{2} \mathrm{O}_{2}$ : hydrogen peroxide; GPx: glutathione peroxidase; PON: paraoxonases; CO: carbon monoxide; Trx: thioredoxin; SR: sarcoplasmic reticulum; SERCA: sarcoplasmic reticulum ATPase; HNE: 4-hydroxyl 2-nonenal; COX: cyclooxygenase; RAAS: renin- angiotensin-aldosterone system; IRS: insulin receptor substrate; PI3K: phosphatidylinositol 3-kinase; RBP: retinol-binding protein; GLUT: glucose uptake transporter; $\mathrm{AT}_{1} \mathrm{R}$ : angiotensin II type 1 receptor; VSMCs: vascular smooth muscle cells; NF-kB: nuclear factor-kappa B; LOX: lipooxygenase; VCAM: ICAM; PDGF: platelet-derived growth factor; SMC: smooth muscle cells; MMP: matrix metalloproteinases; IGF-1: insulin-like growth factor-1; FAO: Fatty acid oxidation; PCl: percutaneous coronary intervention; DES: drug eluting stent}

\section{Acknowledgements}

Not applicable

\section{Authors' contributions}

ARE and AAF conceptualized the review study. ARE did the first draft. ARE and AAF reviewed the first draft. The authors read and approved the final manuscript.

\section{Funding}

Not applicable

\section{Availability of data and materials Not applicable}

Ethics approval and consent to participate Not applicable

Consent for publication

All authors agree to the publication of this article 


\section{Competing interests}

The authors declare that there are no competing interests

\section{Author details}

'Department of Physiology, College of Medicine, Ladoke Akintola University of Technology, Ogbomoso, Oyo State, Nigeria. ${ }^{2}$ Reproductive Biology and Toxicology Research Laboratories, Oasis of Grace Hospital, Osogbo, Osun State, Nigeria. ${ }^{3}$ Department of Chemical Sciences, Kings University, Odeomu, Osun, Nigeria.

\section{Received: 13 July 2020 Accepted: 26 January 2021}

\section{Published online: 27 February 2021}

\section{References}

1. Grundy SM, Cleeman JI, Daniels SR, Donato KA, Eckel RH, et al. Diagnosis and management of the metabolic syndrome: an American Heart Association/National Heart, Lung, and Blood Institute Scientific Statement. Circulation. 2005:112:2735-52

2. Han JC, Lawlor DA, Kimm SY. Childhood obesity. Lancet. 2010;375(9727): 1737-48.

3. Malik VS, Willett WC, Hu FB. Global obesity: trends, risk factors and policy implications. Nature Reviews Endocrinol. 2013;9:13-27.

4. Kuklina EV, Tong X, George MG, Bansil P. Epidemiology and prevention of stroke: a worldwide perspective. Expert Review Neurotherapeutics. 2012; 12(2):199-208.

5. Springer SC, Silverstein J, Copeland K. Management of type 2 diabetes mellitus in children and adolescents. Pediatrics. 2013;131: 648-64.

6. Abete P, Napoli C, Santoro G. Age-related decrease in cardiac tolerance to oxidative stress. J Mol Cell Cardiol. 1999;31(1):227-36

7. Brinkley TE, Nicklas BJ, Kanaya AM. Plasma oxidized low-density lipoprotein levels and arterial stiffness in older adults: the health, aging, and body composition study. Hypertension. 2009:53(5):846-52.

8. Gradinaru D, Borsa C, lonescu C, Prada Gl. Oxidized LDL and NO synthesis biomarkers of endothelial dysfunction and ageing. Mech Ageing Dev. 2015; 151:101-13

9. Hossain P, Kawar B, El Nahas M. Obesity and diabetes in the developing world-a growing challenge. N Engl J Med. 2007;356:213-5.

10. Fezeu L, Balkau B, Kengne AP, Sobngwi E, Mbanya JC. Metabolic syndrome in a sub-Saharan African setting: central obesity may be the key determinant. Atherosclerosis. 2007:193:70-6.

11. Ulasi II, ljoma CK, Onodugo OD. A community-based study of hypertension and cardio-metabolic syndrome in semi-urban and rural communities in Nigeria. BMC Health Serv Res. 2010;10:71.

12. Hosseinpanah F, Barzin M, Sheikholeslami F, Azizi F. Effect of different obesity phenotypes on cardiovascular events in Tehran Lipid and Glucose Study (TLGS). Am J Cardiol. 2011;107:412-6.

13. Harzallah F, Alberti H, Ben KF. The metabolic syndrome in an Arab population: a first look at the new International Diabetes Federation criteria. Diabet Med. 2006:23:441-4

14. Abdul-Rahim HF, Husseini A, Bjertness E, Giacaman R, Gordon NH. The metabolic syndrome in the West Bank population: an urban-rural comparison. Diabetes Care. 2001;24:275-9.

15. Bener A, Zirie M, Musallam M, Khader YS, Al-Hamaq AO. Prevalence of metabolic syndrome according to Adult Treatment Panel III and International Diabetes Federation criteria: a population-based study. Metab Syndr Relat Disord. 2009;7:221-9.

16. Sibai A. Prevalence and correlates of metabolic syndrome in an adult Lebanese population. CVD Prevention and Control. 2008;3:83-90.

17. Ervin B. Prevalence of Metabolic Syndrome Among Adults 20 Years of Age and Over, by Sex, Age, Race and Ethnicity, and Body Mass Index: United States, 2003-2006. Natl Health Stat Report. 2009;5:1-7.

18. Grundy SM. Metabolic syndrome pandemic. Arterioscler Thromb Vasc Biol. 2008;28:629-36.

19. Esposito K, Giugliano F, Martedì E, Feola G, Marfella R, et al. High proportions of erectile dysfunction in men with the metabolic syndrome. Diabetes Care. 2005:28:1201-3.

20. Méndez-Sánchez N, Chavez-Tapia NC, Motola-Kuba D, Sanchez-Lara K, Ponciano-Rodríguez $\mathrm{G}$, et al. Metabolic syndrome as a risk factor for gallstone disease. World J Gastroenterol. 2005;11:1653-7.
21. Ajayi AF, Akhigbe RE, Ajayi LO. Activation of Cardiac TNF-a In Altered Thyroid State-Induced Cardiometabolic Disorder. J Cardiovasc Disease Res. 2017:8(4):151-6.

22. Kelli HM, Kassas I, Lattouf OM. Cardio Metabolic Syndrome: A Global Epidemic. J Diabetes Metab. 2015;6:3.

23. Castro JP, El-Atat FA, McFarlane SI, Aneja A, Sowers JR. Cardiometabolic syndrome: pathophysiology and treatment. Curr Hypertens Rep. 2003:5:393401.

24. Petersen KF, Dufour S, Savage DB, Bilz S, Solomon G, et al. The role of skeletal muscle IR in the pathogenesis of the metabolic syndrome. Proc Natl Acad Sci USA. 2007:104:12587-94.

25. Abate N, Garg A, Peshock RM, Stray-Gundersen J, Adams-Huet B, Grundy SM. Relationship of generalized and regional adiposity to insulin sensitivity in men with NIDDM. Diabetes. 1996;45:1684-93.

26. Pouliot MC, Despres JP, Nadeau A, et al. Visceral obesity in men. Associations with glucose tolerance, plasma insulin, and lipoprotein levels. Diabetes. 1992:41:826-34.

27. Lewis GF, Uffelman KD, Szeto LW, Weller B, Steiner G. Interaction between FFAs and insulin in the acute control of very low density lipoprotein production in humans. J Clin Invest. 1995;95:158-66.

28. Zhang YL, Hernandez-Ono A, Ko C, Yasunaga K, Huang LS, Ginsberg HN Regulation of hepatic apolipoprotein B-lipoprotein assembly and secretion by the availability of fatty acids. I. Differential response to the delivery of fatty acids via albumin or remnant-like emulsion particles. J Biol Chem. 2004;279:19362-74.

29. Mittendorfer B, Liem O, Patterson BW, Miles JM, Klein S. What does the measurement of wholebody fatty acid rate of appearance in plasma by using a fatty acid tracer really mean? Diabetes. 2003:52:1641-8.

30. Mittendorfer B, Patterson BW, Klein S. Effect of sex and obesity on basal VLDL-triacylglycerol kinetics. Am J Clin Nutr. 2003;77:573-9.

31. Steinberg HO, Tarshoby M, Monestel R, et al. Elevated circulating FFA levels impair endothelium-dependent vasodilation. J Clin Invest. 1997:100:1230-9.

32. Perseghin G, Petersen K, Shulman Gl. Cellular mechanism of IR: potential links with inflammation. Int J Obes Relat Metab Disord. 2003;27(Suppl 3):S6-11.

33. Crespo J, Cayon A, Fernandez-Gil P, et al. Gene expression of tumor necrosis factor alpha and TNF-receptors, p55 and p75, in nonalcoholic steatohepatitis patients. Hepatology. 2001;34:1158-63.

34. Park SH, Kim BI, Yun JW, et al. IR and C-reactive protein as independent risk factors for non-alcoholic fatty liver disease in non-obese Asian men. J Gastroenterol Hepatol. 2004;19:694-8.

35. Baggiolini M, Loetscher $P$, Moser B. Interleukin-8 and the chemokine family. Int J Immunopharmacol. 1995;17:103-8.

36. Christiansen T, Richelsen B, Bruun JM. Monocyte chemoattractant protein-1 is produced in isolated adipocytes, associated with adiposity and reduced after weight loss in morbid obese subjects. Int J Obes (Lond). 2005;29:146-50.

37. Berg AH, Combs TP, Du X, Brownlee M, Scherer PE. The adipocyte-secreted protein Acrp30 enhances hepatic insulin action. Nat Med. 2001;7:947-53.

38. Yamauchi T, Kamon J, Minokoshi Y, et al. Adiponectin stimulates glucose utilization and fatty acid oxidation by activating AMP-activated protein kinase. Nat Med. 2002;8:1288-95.

39. Abate N, Garg A, Peshock RM, Stray-Gundersen J, Grundy SM. Relationships of generalized and regional adiposity to insulin sensitivity in men. J Clin Invest. 1995:96:88-98.

40. Ross R, Aru J, Freeman J, Hudson R, Janssen I. Abdominal adiposity and IR in obese men. Am J Physiol Endocrinol Metab. 2002;282:E657-63.

41. Nielsen S, Guo Z, Johnson CM, Hensrud DD, Jensen MD. Splanchnic lipolysis in human obesity. J Clin Invest. 2004;113:1582-8.

42. Havel RJ, Kane JP, Balasse EO, Segel N, Basso LV. Splanchnic metabolism of FFAs and production of triglycerides of very low density lipoproteins in normotriglyceridemic and hypertriglyceridemic humans. J Clin Invest. 1970; 49:2017-35

43. Davis FM, Gallagher K. Epigenetic Mechanisms in Monocytes/Macrophages Regulate Inflammation in Cardiometabolic and Vascular Disease. Arterioscler Thromb Vasc Biol. 2019;39:00-00. DOl: https://doi.org/10.1161/ATVBAHA.118.312135.

44. Kirk EP, Klein S. Pathogenesis and Pathophysiology of the Cardiometabolic Syndrome. J Clin Hypertens (Greenwich). 2009:11(12):761-5.

45. Apel K, Hirt H. Reactive oxygen species: Metabolism, Oxidative Stress, and Signal Transduction. Annu. Rev. Plant Biol. 2004;55:373-99.

46. Keshari AK, Farooqi $\mathrm{H}$. Evaluation of the effect of hydrogen peroxide $\left(\mathrm{H}_{2} \mathrm{O} 2\right)$ on haemoglobin and the protective effect of glycine" International J Sci Tecnhnoledge. 2014;2(2):36-41. 
47. Gueteens G, De Boeck G, Highley M, Osterom AT, De Bruijn EA. Oxidative DNA damage: Biological significance and methods of analysis. Crit Rev Clin Lab Sci. 2002;39:331-457.

48. Martin TA, Harrison G, Mansel RE, Jiang WG. The role of the CD44/ezrin complex in cancer metastasis. Crit Rev Oncol Hematol. 2003;46:165-86.

49. Espinosa-Diez C, Miguel V, Mennerich D, Kietzmann T, Sánchez-Pérez P, Cadenas S, Lamas S. Antioxidant responses and cellular adjustments to oxidative stress. Redox Biology. 2015;6:183-97.

50. Sack MN, Fyhrquist FY, Saijonmaa OJ, Fuster V, Kovacic JC. Basic Biology of Oxidative Stress and the Cardiovascular System. J Am Coll Cardiol. 2017;70:196-211.

51. Lee MY, Griendling KK. Redox signaling, vascular function, and hypertension. Antioxidants Redox Signaling. 2008;10(6):1045-59.

52. Harris CM, Sanders SA, Massey V. Role of the flavin midpoint potential and NAD binding in determining NAD versus oxygen reactivity of xanthine oxidoreductase. J Biol Chem. 1999:274(8):4561-9.

53. Landmesser U, Spiekermann S, Preuss C, et al. Angiotensin II induces endothelial xanthine oxidase activation: role for endothelial dysfunction in patients with coronary disease. Arterioscler Thromb Vasc Biol. 2007;27:943-8.

54. Nauseef WM. Assembly of the phagocyte NADPH oxidase. Histochemistry and Cell Biology. 2004;122(4):277-91.

55. Ando S, Kaibuchi K, Sasaki T, Hiraoka K, Nishiyama T, Mizuno T, Asada M, Nunoi H, Matsuda I, Matsuura Y. Post-translational processing of rac p21s is important both for their interaction with the GDP/GTP exchange proteins and for their activation of NADPH oxidase. Journal of Biological Chemistry. 1999;267(36):25709-13.

56. Diebold BA, Bokoch GM. Molecular basis for Rac2 regulation of phagocyte NADPH oxidase. Nature Immunology. 2001;2(3):211-5.

57. Cave AC, Brewer AC, Narayanapanicker A, Ray R, Grieve DJ, Walker S. NADPH oxidases in cardiovascular health and disease. Antioxidan Redox Signaling. 2006;8(5-6):691-728

58. Ide T, Tsutsui H, Hayashidani S, Kang D, Suematsu N, Nakamura K, Utsumi H, Hamasaki N, Takeshita A. Mitochondrial DNA damage and dysfunction associated with oxidative stress in failing hearts after myocardial infarction. Circulation Research. 2001;88(5):529-35.

59. Valenti VE, de Abreu LC, Ferreira C and Saldiva PHN. Reactive Oxygen Species and Cardiovascular Diseases, Oxidative Stress and Diseases, Dr. Volodymyr Lushchak (Ed.), InTech, 2012. ISBN: 978-953-51-0552-7, Available from: http://www.intechopen.com/books/oxidative-stress-anddiseases/ reactive-oxygen-species-and-cardiovascular-diseases.

60. Verhaar MC, Westerweel PE, van Zonneveld AJ, Rabelink TJ. Free radical production by dysfunctional eNOS. Heart. 2004;90(5):494-5 ISSN 1468-201X.

61. Li J. M, Shah A.M. Endothelial cell superoxide generation: regulation and relevance for cardiovascular pathophysiology. Am J Physiol 2004;287(5): R1014-R1030.R1030

62. Matsuzawa A, Ichijo H. Stress-responsive protein kinases in redox-regulated apoptosis signaling. Antioxidants and Redox Signaling. 2005;7(3-4):472-81.

63. Valenti VE, de Abreu LC, Ferreira C and Saldiva PHN. Reactive Oxygen Species and Cardiovascular Diseases, Oxidative Stress and Diseases, Dr. Volodymyr Lushchak (Ed.), 2012, ISBN: 978-953-51-0552-7, InTech, Available from: http://www.intechopen.com/books/oxidative-stress-anddiseases/ reactive-oxygen-species-and-cardiovascular-diseases.

64. Münzel T, Camici GG, Maack C, Bonetti NR, Fuster V, Kovacic JC. Impact of Oxidative Stress on the Heart and Vasculature. J Am College Cardiol. 2017; 70(2):212-29.

65. Freed JK, Gutterman DD. Mitochondrial reactive oxygen species and vascular function: less is more. Arterioscler Thromb Vasc Biol. 2013;33:673-5.

66. Stocker R, Keaney JF Jr. Role of oxidative modifications in atherosclerosis. Physiol Rev. 2004;84:1381-478.

67. Griendling KK, Sorescu D, Lassègue B, Ushio-Fukai M. Modulation of protein kinase activity and gene expression by reactive oxygen species and their role in vascular physiology and pathophysiology. Arterioscler Thromb Vasc Biol. 2000:20:2175-83.

68. Förstermann U. Nitric oxide and oxidative stress in vascular disease. Pflugers Archiv. 2010;459:923-39.

69. Förstermann U, Münzel T. Endothelial nitric oxide synthase in vascular disease: from marvel to menace. Circulation. 2006;113:1708-14.

70. Gryglewski RJ, Palmer RM, Moncada S. Superoxide anion is involved in the breakdown of endothelium-derived vascular relaxing factor. Nature. 1986; 320:454-6.

71. Beckman JS. Oxidative damage and tyrosine nitration from peroxynitrite Chem Res Toxicol. 1996;9:836-44.
72. Laursen JB, Somers M, Kurz S, et al. Endothelial regulation of vasomotion in apoE-deficient mice: implications for interactions between peroxynitrite and tetrahydrobiopterin. Circulation. 2001;103:1282-8.

73. Harrison DG, Chen W, Dikalov S, Li L. Regulation of endothelial cell tetrahydrobiopterin pathophysiological and therapeutic implications. Adv Pharmacol. 2010;60:107-32

74. Li H, Horke S, Förstermann U. Vascular oxidative stress, nitric oxide and atherosclerosis. Atherosclerosis. 2014;237:208-19.

75. Schiffrin EL. Remodeling of resistance arteries in essential hypertension and effects of antihypertensive treatment. Am J Hypertension. 2004;17(12):1192200.

76. Korsgaard N, Aalkjaer C, Heagerty AM, Izzard AS, Mulvany MJ. Histology of subcutaneous small arteries from patients with essential hypertension. Hypertension. 1993;22(4):523-6.

77. Rizzoni D, Porteri E, Guefi D, Piccoli A, Castellano M, Pasini G, Muiesan ML, Mulvany MJ, Rosei EA. Cellular hypertrophy in subcutaneous small arteries of patients with renovascular hypertension. Hypertension. 2000;35(4):931-5.

78. Tribble DL, Gong EL, Leeuwenburgh C. Fatty streak formation in fat-fed mice expressing human copper-zinc superoxide dismutase. Arterioscler Thromb Vasc Biol. 1997;17:1734-40.

79. Sentman ML, Brännstrom T, Westerlund S. Extracellular superoxide dismutase deficiency and atherosclerosis in mice. Arterioscler Thromb Vasc Biol. 2001;21:1477-82.

80. Yang $H$, Roberts $L$, Shi MJ. Retardation of atherosclerosis by overexpression of catalase or both Cu/Zn-superoxide dismutase and catalase in mice lacking apolipoprotein E. Circ Res. 2004;95:1075-81.

81. Fukai T, Ushio-Fukai M. Superoxide dismutases: role in redox signaling, vascular function, and diseases. Antioxid Redox Signal. 2011;15:1583-606.

82. Zhang Y, Griendling KK, Dikalova A, Owens GK, Taylor WR. Vascular hypertrophy in angiotensin I-induced hypertension is mediated by vascular smooth muscle cell-derived $\mathrm{H}_{2} \mathrm{O}_{2}$. Hypertension. 2005;46:732-7.

83. Lewis $\mathrm{P}$, Stefanovic N, Pete J. Lack of the antioxidant enzyme glutathione peroxidase-1 accelerates atherosclerosis in diabetic apolipoprotein Edeficient mice. Circulation. 2007:115:2178-87.

84. Torzewski M, Ochsenhirt V, Kleschyov AL. Deficiency of glutathione peroxidase1 accelerates the progression of atherosclerosis in apolipoprotein E-deficient mice. Arterioscler Thromb Vasc Biol. 2007;27:850-7.

85. Yoshida T, Maulik N, Engelman RM. Glutathione peroxidase knockout mice are susceptible to myocardial ischemia reperfusion injury. Circulation. 1997; 96:I1216-20

86. Blankenberg S, Rupprecht HJ, Bickel C. AtheroGene Investigators. Glutathione peroxidase 1 activity and cardiovascular events in patients with coronary artery disease. N Engl J Med. 2003;349:1605-13.

87. Guo Z, Ran Q, Roberts LJ. Suppression of atherogenesis by overexpression of glutathione peroxidase-4 in apolipoprotein E-deficient mice. Free Radic Biol Med. 2008;44:343-52.

88. Witte I, Foerstermann U, Devarajan A, Reddy ST, Horke S. Protectors or traitors: the roles of PON2 and PON3 in atherosclerosis and cancer. J Lipids. 2012;2012:342806

89. Huang Y, Wu Z, Riwanto M. Myeloperoxidase, paraoxonase-1, and HDL form a functional ternary complex. J Clin Invest. 2013;123:3815-28.

90. Horke $S$, Witte I, Wilgenbus $P$, Krüger M, Strand D, Förstermann U. Paraoxonase-2 reduces oxidative stress in vascular cells and decreases endoplasmic reticulum stress-induced caspase activation. Circulation. 2007;115:2055-64.

91. Ng CJ, Bourquard N, Grijalva V. Paraoxonase-2 deficiency aggravates atherosclerosis in mice despite lower apolipoprotein-B containing lipoproteins: anti-atherogenic role for paraoxonase-2. J Biol Chem. 2006;281: 29491-500.

92. Schweikert EM, Devarajan A, Witte I. PON3 is upregulated in cancer tissues and protects against mitochondrial superoxide-mediated cell death. Cell Death Differ. 2012;19:1549-60.

93. Shih DM, Xia YR, Wang XP. Decreased obesity and atherosclerosis in human paraoxonase 3 transgenic mice. Circ Res. 2007;100:1200-7.

94. Marsillach J, Camps J, Beltran-Debón R. Immunohistochemical analysis of paraoxonases- 1 and 3 in human atheromatous plaques. Eur J Clin Invest. 2011:41:308-14

95. Stocker R, Perrella MA. Heme oxygenase-1: a novel drug target for atherosclerotic diseases? Circulation. 2006:114:2178-89.

96. Taille C, El-Benna J, Lanone S. Induction of heme oxygenase-1 inhibits NAD(P) H oxidase activity by down-regulating cytochrome b558 expression via the reduction of heme availability. J Biol Chem. 2004;279:28681-8. 
97. Jiang F, Roberts SJ. Datla Sr., Dusting GJ. NO modulates NADPH oxidase function via heme oxygenase-1 in human endothelial cells. Hypertension. 2006:48:950-7.

98. Hilgers $\mathrm{RH}$, Kundumani-Sridharan V, Subramani J. Thioredoxin reverses age related hypertension by chronically improving vascular redox and restoring eNOS function. Sci Transl Med. 2017;9:eaaf6094.

99. May JM. How does ascorbic acid prevent endothelial dysfunction? Free Radic Biol Med. 2000;28:1421-9.

100. Heller R, Unbehaun A, Schellenberg B, Mayer B, Werner-Felmayer G, Werner ER. L-Ascorbic acid potentiates endothelial nitric oxide synthesis via a chemical stabilization of tetrahydrobiopterin. J Biol Chem. 2001;276:40-7.

101. Wallerath T, Deckert G, Ternes T. Resveratrol, a polyphenolic phytoalexin present in red wine, enhances expression and activity of endothelial nitric oxide synthase. Circulation. 2002;106:1652-8.

102. Wallerath T, Li H, Gödtel-Ambrust U, Schwarz PM, Förstermann U. A blend of polyphenolic compounds explains the stimulatory effect of red wine on human endothelial NO synthase. Nitric Oxide. 2005;12:97-104.

103. Agarwal A, Sekhon LH. Oxidative stress and antioxidants for idiopathic oligoasthenoteratospermia: Is it justified? Indian J Urol. 2011;27:74-85.

104. Agarwal A, Saleh RA. Role of oxidants in male infertility: rationale, significance, and treatment. Urol Clin North Am. 2002;29:817-27.

105. Griveau JF, Dumont E, Renard B, Callegari JP, Lannou D. Reactive oxygen species, lipid peroxidation and enzymatic defense systems in human spermatozoa. J Reprod Fertil. 1995;103:17-26.

106. Hool L. C, Corry B. Redox control of calcium channels: from mechanisms to therapeutic opportunities. Antioxidant and Redox Signal 2007; 4:409-435.

107. Cherednichenko G, Zima AV, Feng W, Schaefer S, Blatter LA, Pessah IN. $\mathrm{NADH}$ oxidase activity of rat cardiac sarcoplasmic reticulum regulates calcium induced calcium release. Circulation Research. 2004;94(4):478-86.

108. Sanchez G, Escobar M, Pedrozo Z, Macho P, Domenech R, Hartel S. Exercise and tachycardia increase NADPH oxidase and ryanodine receptor-2 activity: possible role in cardioprotection. Cardiovascular Research. 2008;77(2):380-6.

109. Yi XY, Li VX, Zhang F, Yi F, Matson DR, Jiang MT. Characteristics and actions of $\mathrm{NAD}(\mathrm{P}) \mathrm{H}$ oxidase on the sarcoplasmic reticulum of coronary artery smooth muscle. Am J Physiol Heart Circulatory Physiol. 2006;290(3):H1136-44.

110. Zeng Q, Zhou Q, Yao F, O'Rourke S. T, Sun C. Endothelin-1 regulates cardiac Ltype calcium channels via NAD(P) H oxidase-derived superoxide. J Pharmacol Experimental Therapeutics 2006; 326(3): 732-738.

111. Montague CT, O'Rahilly S. The perils of portliness: causes and consequences of visceral adiposity. Diabetes. 2000;49:883-8.

112. Matsuzawa $Y$, Funahashi T, Nakamura T. Molecular mechanism of metabolic syndrome $X$ : Contribution of adipocytokines adipocyte-derived bioactive substances. Ann. N. Y.Acad Sci. 1999;892:146-54.

113. Spiegelman BM, Flier JS. Obesity and the regulation of energy balance. Cell. 2001;104:531-43.

114. Kahn BB, Flier JS. Obesity and IR. J. Clin. Invest. 2000;106:473-81.

115. Furukawa S, Fujita T, Shimabukuro M, Iwaki M, Yamada Y, Nakajima Y, Nakayama O, Makishima M, Matsuda M, Shimomura I. Increased oxidative stress in obesity and its impact on metabolic syndrome. J Clin Invest. 2004; 114:1752-61.

116. Devaraj S, Wang-Polagruto J, Polagruto J, Keen CL, Jialal I. High-fat, energydense, fast-food-style breakfast results in an increase in oxidative stress in metabolic syndrome. Metab Clin Exp. 2008;57:867-70.

117. Johnson JB, Summer W, Cutler RG, Martin B, Hyun D-H, Dixit VD, Pearson M, Nassar M, Telljohann R, Tellejohan R, Maudsley S, Carlson O, John S, Laub DR, Mattson MP. Alternate day calorie restriction improves clinical findings and reduces markers of oxidative stress and inflammation in overweight adults with moderate asthma. Free Radic Biol Med. 2007:42:665-74.

118. Hattori Y, Akimoto K, Gross SS, Hattori S, Kasai K. Angiotensin-II-induced oxidative stress elicits hypoadiponectinaemia in rats. Diabetologia. 2005;48:1066-74.

119. Soares AF, Guichardant M, Cozzone D, Bernoud-Hubac N, Bouzaidi-Tiali N, Lagarde M, Geloen A. Effects of oxidative stress on adiponectin secretion and lactate production in 3T3-L1 adipocytes. Free Radic Biol Med. 2005;38:882-9.

120. Chen B, Wei J, Wang W, Cui G, Zhao Y, Zhu X, Zhu M, Guo W, Yu J. Identification of signaling pathways involved in aberrant production of adipokines in adipocytes undergoing oxidative stress. Arch Med Res. 2009:40:241-8.

121. Sakurai T, Izawa T, Kizaki T, Ogasawara JE, Shirato K, Imaizumi K, Takahashi K, Ishida $\mathrm{H}$, Ohno $\mathrm{H}$. Exercise training decreases expression of inflammationrelated adipokines through reduction of oxidative stress in rat white adipose tissue. Biochem Biophys Res Commun. 2009;379:605-9.
122. Shimomura I. Enhanced expression of PAl-1 in visceral fat: possible contributor to vascular disease in obesity. Nat. Med. 1996;2:800-3.

123. Hotamisligil GS, Shargill NS, Spiegelman BM. Adipose expression of tumor necrosis factor-a: direct role in obesity-linked IR. Science. 1993;259:87-91.

124. Uysal KT, Wiesbrock SM, Marino MW, Hotamisligil GS. Protection from obesity-induced IR in mice lacking TNF-alpha function. Nature. 1997;389: 610-4.

125. Fruebis J, et al. Proteolytic cleavage product of 30-kDa adipocyte complement-related protein increases fatty acid oxidation in muscle and causes weight loss in mice. Proc. Natl. Acad. Sci. U. S. A. 2001;98:2005-10.

126. Yamauchi $T$, et al. The fat-derived hormone adiponectin reverses IR associated with both lipoatrophy and obesity. Nat. Med. 2001;7:941-6.

127. Maeda N, et al. Diet-induced IR in mice lacking adiponectin/ACRP30. Nat. Med. 2002:8:731-7.

128. Okamoto $Y$, et al. Adiponectin reduces atherosclerosis in apolipoprotein Edeficient mice. Circulation. 2002;106:2767-70.

129. Matsuda M, et al. Role of adiponectin in preventing vascular stenosis. The missing link of adipovascular axis. J. Biol. Chem. 2002;277:37487-91.

130. Yamauchi T, et al. Globular adiponectin protected ob/ob mice from diabetes and apoE-deficient mice from atherosclerosis. J. Biol. Chem. 2003; 278:2461-8

131. Zarrouki B, Soares AF, Guichardant M, Lagarde M, Geloen A. The lipid peroxidation end-product 4-HNE induces COX-2 expression through p38MAPK activation in 3T3-L1 adipose cell. FEBS Lett. 2007;581:2394-400.

132. Wang Z, Dou X, Gu D, Shen C, Yao T, Nguyen V, Braunschweig C, Song Z. 4Hydroxynonenal differentially regulates adiponectin gene expression and secretion via activating PPARY and accelerating ubiquitin-proteasome degradation. Mol Cell Endocrinol. 2012;349:222-31.

133. Cassis LA, Police SB, Yiannikouris F, Thatcher SE. Local adipose tissue reninangiotensin system. Curr Hypertens Rep. 2008;10:93-8.

134. Dandona P, Dhindsa S, Ghanim H, Chaudhuri A. Angiotensin II and inflammation: the effect of angiotensinconverting enzyme inhibition and angiotensin II receptor blockade. J Hum Hypertens. 2007;21:20-7.

135. Koh KK, Oh PC, Quon MJ. Does reversal of oxidative stress and inflammation provide vascular protection? Cardiovasc Res. 2009;81:649-59.

136. Skultetyova D, Filipova S, Riecansky I, Skultety J. The role of angiotensin type 1 receptor in inflammation and endothelial dysfunction. Recent Pat Cardiovasc Drug Discov. 2007;2:23-7.

137. Otani H. Oxidative Stress as Pathogenesis of Cardiovascular Risk Associated with Metabolic Syndrome. Antioxidants Redox Signaling. 2011;15(7):1911-26.

138. Bendall JK, Alp NJ, Warrick N, Cai S, Adlam D, Rockett K, Yokoyama M, Kawashima S, Channon KM. Stoichiometric relationships between endothelial tetrahydrobiopterin, endothelial NO synthase (eNOS) activity, and eNOS coupling in vivo: insights from transgenic mice with endothelialtargeted GTP cyclohydrolase 1 and eNOS overexpression. Circ Res. 2005;97: 864-71.

139. Schulz E, Jansen T, Wenzel P, Daiber A, Munzel T. Nitric oxide, tetrahydrobiopterin, oxidative stress, and endothelial dysfunction in hypertension. Antioxid Redox Signal. 2008;10:1115-26.

140. Akhigbe R, Ajayi A. Testicular toxicity following chronic codeine administration is via oxidative DNA damage and up-regulation of NO/TNF-a and caspase 3 activities. PLoS ONE. 2020;15(3):e0224052.

141. Dickhout JG, Hossain GS, Pozza LM, Zhou J, Lhotak S, Austin RC. Peroxynitrite causes endoplasmic reticulum stress and apoptosis in human vascular endothelium: implications in atherogenesis. Arterioscler Thromb Vasc Biol. 2005;25:2623-9.

142. Duda DG, Fukumura D, Jain RK. Role of eNOS in neovascularization: NO for endothelial progenitor cells. Trends Mol Med. 2004;10:143-5.

143. Luque Contreras D, Vargas Robles H, Romo E, Rios A, Escalante B. The role of nitric oxide in the post-ischemic revascularization process. Pharmacol Ther. 2006;112:553-63.

144. Archuleta TL, Lemieux AM, Saengsirisuwan V, Teachey MK, Lindborg KA, Kim JS, Henriksen EJ. Oxidant stress-induced loss of IRS-1 and IRS-2 proteins in rat skeletal muscle: role of p38 MAPK. Free Radic Biol Med. 2009;47:1486-93.

145. Tamori Y, Sakaue H, Kasuga M. RBP4, an unexpected adipokine. Nat Med. 2006;12:30-1; discussion 31.

146. Muoio DM, Newgard CB. Metabolism: A is for adipokine. Nature. 2005:436: $337-8$.

147. Beckman JS, Crow JP. Pathological implications of nitric oxide, superoxide and peroxynitrite formation. Biochem. Soc. Trans. 1993;21:330-4. 
148. Beckman JS, Beckman TW, Chen J. Apparent hydroxyl radical production of peroxynitrite: implications for endothelial injury from nitric oxide and superoxide. Proc. Natl. Acad. Sci. USA. 1990;87:1620-4.

149. Manrique C, Lastra G, Gardner M, Sowers JR. The Renin Angiotensin Aldosterone System in Hypertension: Roles of IR and Oxidative Stress. Med Clin North Am. 2009;93(3):569-82. https://doi.org/10.1016/j.mcna.2009.02. 014

150. Madamanchi NR, Vendrov A, Runge MS. Oxidative stress and vascular disease. Arterioscler Thromb Vasc Biol. 2005;25:29-38.

151. Sydow K, Munzel T. ADMA and oxidative stress. Atheroscler Suppl. 2003;4: 41-51.

152. Böger RH, Sydow K, Borlak J, Thum T, Lenzen H, Schubert B, Tsikas D, BodeBöger SM. LDL cholesterol upregulates synthesis of asymmetrical dimethylarginine in human endothelial cells: involvement of Sadenosylmethionine-dependent methyltransferases. Circ Res. 2000;87:99-105.

153. Zou MH, Shi C, Cohen RA. Oxidation of the zinc-thiolate complex and uncoupling of endothelial nitric oxide synthase by peroxynitrite. J Clin Invest. 2002;109:817-26.

154. Massiera F, Bloch-Faure M, Ceiler D, et al. Adipose angiotensinogen is involved in adipose tissue growth and blood pressure regulation. FASEB J. 2001:15:2727-9.

155. Cooper SA, Whaley-Connell A, Habibi J, et al. Renin-angiotensin-aldosterone system and oxidative stress in cardiovascular IR. Am J Physiol Heart Circ Physiol. 2007;293:H2009-23.

156. Mehta PK, Griendling KK. Angiotensin II cell signaling: physiological and pathological effects in the cardiovascular system. Am J Physiol, Cell Physiol. 2007;292:C82-97.

157. Johar S, Cave AC, Narayanapanicker A, et al. Aldosterone mediates angiotensin II-induced interstitial cardiac fibrosis via a Nox2-containing NADPH oxidase. FASEB J. 2006;20:1546-8.

158. Beswick RA, Zhang $H$, Marable D, et al. Long-term antioxidant administration attenuates mineralocorticoid hypertension and renal inflammatory response. Hypertension. 2001;37:781-6.

159. CS, Cheng ZJ, Tikkanen I, et al. Endothelial dysfunction and xanthine oxidoreductase activity in rats with human renin and angiotensinogen genes. Hypertension. 2001;37:414-8.

160. Laakso J, Mervaala E, Himberg JJ, et al. Increased kidney xanthine oxidoreductase activity in saltinduced experimental hypertension. Hypertension. 1998;32:902-6.

161. Griendling KK, Minieri CA, Ollerenshaw JD, et al. Angiotensin II stimulates NADH and NADPH oxidase activity in cultured vascular smooth muscle cells. Circ Res. 1994;74:1141-8.

162. Brandes RP. Triggering mitochondrial radical release: a new function for NADPH oxidases. Hypertension. 2005:45:847-8

163. Kimura S, Zhang GX, Nishiyama A, Shokoji T, Yao L, Fan YY, Rahman M, Abe $Y$. Mitochondria-derived reactive oxygen species and vascular MAP kinases: comparison of angiotensin II and diazoxide. Hypertension. 2005;45:438-44.

164. Reinehr R, Becker S, Eberle A, Grether-Beck S, Haussinger D. Involvement of NADPH oxidase isoforms and Src family kinases in CD95-dependent hepatocyte apoptosis. J Biol Chem. 2005;280:27179-94.

165. Touyz RM, Yao G, Schiffrin EL. c-Src induces phosphorylation and translocation of p47phox: role in superoxide generation by angiotensin II in human vascular smooth muscle cells. Arterioscler Thromb Vasc Biol. 2003;23:981-7.

166. Kroller-Schon S, Steven S, Kossmann S, Scholz A, Daub S, Oelze M, Xia N, Hausding M, Mikhed Y, Zinßius E, Mader M, Stamm P, Treiber N, Scharffetter-Kochanek K, Li H, Schulz E, Wenzel P, Munzel T, Daiber A. Molecular Mechanisms of the Crosstalk Between Mitochondria and NADPH Oxidase Through Reactive Oxygen Species-Studies in White Blood Cells and in Animal Models. Antioxid. Redox Signal. 2014;20:247-66.

167. Ballinger SW, Patterson C, Knight-Lozano CA, et al. Mitochondrial integrity and function in atherogenesis. Circulation. 2002;106:544-9.

168. Garelnabi M, Kakumanu S, Litvinov D. Role of Oxidized Lipids in Atherosclerosis. In: Oxidative Stress and Diseases. Ed: Dr. Volodymyr Lushchak. ISBN: 978-953-51-0552-7. InTech. Available from: http://www. intechopen.com/books/oxidative-stress-and-diseases/role-of-oxidized-lipidsin-atherosclerosis.

169. Collot-Teixeira S, Martin J, McDermott-Roe C, Poston R, McGregor JL. CD36 and macrophages in atherosclerosis. Cardiovasc Res. 2007;75:468-77.

170. Rahaman SO, Lennon DJ, Febbraio M, Podrez EA, Hazen SL, Silverstein RL. A CD36-dependent signaling cascade is necessary for macrophage foam cell formation. Cell Metab. 2006:4:211-21.
171. Thorne RF, Mhaidat NM, Ralston KJ, Burns GF. CD36 is a receptor for oxidized high density lipoprotein: implications for the development of atherosclerosis. FEBS Lett. 2007;581:1227-32.

172. Moore KJ, Freeman MW. Scavenger receptors in atherosclerosis: beyond lipid uptake. Arterioscler Thromb Vasc Biol. 2006;26(8):1702-11.

173. Alcouffe J, Caspar-Bauguil S, Garcia V, Salvayre R, Thomsen M, Benoist H. Oxidized low density lipoproteins induce apoptosis in PHA-activated peripheral blood mononuclear cells and in the Jurkat T-cell line. J Lipid Res. 1999;40(7):1200-10.

174. Coffey MD, Cole RA, Colles SM, Chisolm GM. In vitro cell injury by oxidized low density lipoprotein involves lipid hydroperoxide-induced formation of alkoxyl, lipid, and peroxyl radicals. J Clin Invest. 1995;96:1866-73.

175. Brand K, Eisele T, Kreusel U, Page M, Page S, Haas M, Gerling A, Kaltschmidt C, Neumann FJ, Mackman N, Baeurele PA, Walli AK, Neumeier D. Dysregulation of monocytic nuclear factor-kappa B by oxidized low-density lipoprotein. Arterioscler Thromb Vasc Biol. 1997;17:1901-9.

176. Eligini S, Brambilla M, Banfi C, Camera M, Sironi L, Barbieri SS, Auwerx J, Tremoli E. Colli S. Oxidized phospholipids inhibit cyclooxygenase-2 in human macrophages via nuclear factor-kappaB/lkappaB-and ERK2dependent mechanisms. Cardiovasc Res. 2002;55:406-15.

177. Brand K, Page S, Rogler G, Bartsch A, Brandl R, Knuechel R, Page M, Kaltschmidt C, Baeuerle PA, Neumeier D. Activated transcription factor nuclear factor kappa B is present in the atherosclerotic lesion. J Clin Invest. 1996;97(7):1715-22.

178. Cominacini L, Pasini AF, Garbin U, Davoli A, Tosetti ML, Campagnola M, Rigoni A, Pastorino AM, Lo Cascio V, Sawamura T. Oxidized low density lipoprotein (OxLDL) binding to OxLDL receptor-1 in endothelial cells induces the activation of NF-kappaB through an increased production of intracellular reactive oxygen species. J Biol Chem. 2000;275(17):12633-8.

179. Tanigawa H, Miura S, Matsuo Y, Fujino M, Sawamura T, Saku K. Dominantnegative lox-1 blocks homodimerization of wild-type lox-1-induced cell proliferation through extracellular signal regulated kinase 1/2 activation. Hypertension. 2006;48(2):294-300.

180. Cominacini L, Garbin U, Fratta Pasini A, Paulon T, Davoli A, Campagnola M, Marchi E, Pastorino AM, Gaviraghi G, Lo CV. Lacidipine inhibits the activation of the transcription factor NF-kappaB and the expression of adhesion molecules induced by pro-oxidant signals on endothelial cells. J Hypertens. 1997;15(12 Pt 2):1633-40.

181. Wang G, Woo CW, Sung FL, Siow YL, and O K. Increased monocyte adhesion to aortic endothelium in rats with hyperhomocysteinemia: role of chemokine and adhesion molecules. Arterioscler Thromb Vasc Biol 22: 1777-1783, 2002.

182. Boyle JJ. Macrophage activation in atherosclerosis: pathogenesis and pharmacology of plaque rupture. Curr Vasc Pharmacol. 2005;3:63-8.

183. DiCorleto PE. Cellular mechanisms of atherogenesis. Am J Hypertens. 1993;6: 314S-8S.

184. Myllarniemi M, Calderon L, Lemstrom K, Buchdunger E, Hayry P. Inhibition of platelet-derived growth factor receptor tyrosine kinase inhibits vascular smooth muscle cell migration and proliferation. FASEB J. 1997;11:1119-26.

185. Vinayagamoorthi R, Bobby Z, Sridhar MG. Antioxidants preserve redox balance and inhibit c-Jun-Nterminal kinase pathway while improving insulin signaling in fat-fed rats: evidence for the role of oxidative stress on IRS-1 serine phosphorylation and IR. J Endocrinol. 2008;197:287-96.

186. Igarashi M, Hirata A, Yamaguchi $H$, Tsuchiya $H$, Ohnuma $H$, Tominaga M, Daimon M, Kato T. Candesartan inhibits carotid intimal thickening and ameliorates IR in balloon-injured diabetic rats. Hypertension. 2001; 38:1255-9.

187. Martinet W, Kockx MM. Apoptosis in atherosclerosis:focus on oxidized lipids and inflammation. Curr Opin Lipidol. 2001;12:535-41.

188. Hung YC, Hong MY, Huang GS. Cholesterol loading augments oxidative stress in macrophages. FEBS Lett. 2006;580:849-61.

189. Wainwright CL. Matrix metalloproteinases, oxidative stress and the acute response to acute myocardial ischaemia and reperfusion. Curr Opin Pharmacol. 2004:4:132-8

190. Libby P. The molecular mechanisms of the thrombotic complications of atherosclerosis. J Intern Med. 2008;263:517-27.

191. Levitan EB, Song Y, Ford ES, Liu S. Is nondiabetic hyperglycemia a risk factor for cardiovascular disease? A meta-analysis of prospective studies. Arch Intern Med. 2004;164(19):2147-55 https://doi.org/10.1001/archinte.164.19.2147.

192. Sasso FC, Pafundi PC, Marfella R, Calabrò P, Piscione F, Furbatto F, Esposito G, Galiero R, Gragnano F, Rinald L, Salvatore T, D'Amico M, Adinolfi LE, Sardu S. Adiponectin and insulin resistance are related to restenosis and overall new 
PCl in subjects with normal glucose tolerance: the prospective AIRE Study. Cardiovasc Diabetol. 2019;18:24 https://doi.org/10.1186/s12933-019-0826-0.

193. Orbach A, Halon DA, Jaffe R, Rubinshtein R, Karkabi B, Flugelman MY, Zafrir B. Impact of diabetes and early revascularization on the need for late and repeat procedures. Cardiovasc Diabetol. 2018;17(1):25. https://doi.org/10. 1186/s12933-018-0669-0.

194. Komatsu T, Komatsu S, Nakamura H, Kuroyanagi T, Fujikake A, Hisauchi I, Sakuma M, Nakahara S, Sakai Y, Taguchi I. Insulin resistance as a predictor of the late catch-up phenomenon after drug-eluting stent implantation. Circ J. 2016;80(3):657-62. https://doi.org/10.1253/circj.CJ-15-1012

195. Intine RV, Sarras MP Jr. Metabolic memory and chronic diabetes complications: potential role for epigenetic mechanisms. Curr Diab Rep. 2012;12:551-9.

196. Gillette TG, Hill JA. Readers, writers, and erasers: chromatin as the whiteboard of heart disease. Circ Res. 2015:116:1245-53.

197. Barnes SK, Ozanne SE. Pathways linking the early environment to long-term health and lifespan. Prog Biophys Mol Biol. 2011;106:323-36.

198. Wegner M, Neddermann D, Piorunska-Stolzmann M, Jagodzinski PP. Role of epigenetic mechanisms in the development of chronic complications of diabetes. Diabetes Res Clin Pract. 2014;105:164-75.

199. Keating ST, Plutzky J, El-Osta A. Epigenetic changes in diabetes and cardiovascular risk. Circ Res. 2016;118:1706-22.

200. Yu XY, Geng YJ, Liang JL. High levels of glucose induce "metabolic memory" in cardiomyocyte via epigenetic histone $\mathrm{H} 3$ lysine 9 methylation. Mol Biol Rep. 2012;39:8891-8.

201. Yu XY, Geng YJ, Liang JL. High levels of glucose induce apoptosis in cardiomyocyte via epigenetic regulation of the insulin-like growth factor receptor. Exp Cell Res. 2010;316:2903-9.

202. Dick KJ, Nelson CP, Tsaprouni L. DNA methylation and body-mass index: a genome-wide analysis. Lancet. 2014;383:1990-8.

203. Keating ST, El-Osta A. Epigenetics and metabolism. Circ Res. 2015;116:715-36.

204. Scholze J, Alegria E, Ferri C, Langham S, Stevens W, et al. Epidemiological and economic burden of metabolic syndrome and its consequences in patients with hypertension in Germany, Spain and Italy; a prevalence-based model. BMC Public Health. 2010;10:529.

205. Vancampfort D, Hallgren M, Mugisha J, Hert M, Probst M, Monsieur D, Stubbs B. The Prevalence of Metabolic Syndrome in Alcohol Use Disorders: A Systematic Review and Meta-analysis Alcohol and Alcoholism. 2016; 51(5):515-21.

206. Goodwin RD, Kim JH, Weinberger AH, et al. Symptoms of alcohol dependence and smoking initiation and persistence: a longitudinal study among US adults. Drug Alcohol Depend. 2013;133:718-23.

207. Smothers B, Bertolucci D. Alcohol consumption and healthpromoting behavior in a US household sample: leisure-time physical activity. J Stud Alcohol. 2001:62:467-76.

208. Whang W, Kubzansky LD, Kawachi I, et al. Depression and risk of sudden cardiac death and coronary heart disease in women: results from the Nurses' Health Study. J Am Coll Cardiol. 2009;53:950-8.

209. Buijsse B, Weikert C, Drogan D, Bergmann M, Boeing H. Chocolate consumption in relation to blood pressure and risk of cardiovascular disease in German adults. Eur Heart J. 2010:31:1616-23.

210. Djousse L, Hopkins PN, Arnett DK, Pankow JS, Borecki I, North KE, et al. Chocolate consumption is inversely associated with calcified atherosclerotic plaque in the coronary arteries: the NHLBI Family Heart Study. Clin Nutr. 2011:30:182-7.

211. Shonkoff JP, Garner AS; Committee on Psychosocial Aspects of Child and Family Health; Committee on Early Childhood, Adoption, and Dependent Care; Section on Developmental and Behavioral Pediatrics. The lifelong effects of early childhood adversity and toxic stress. Pediatrics. 2012;129:e232-e246.

212. McCullough ML, Bostick RM, Mayo TL. Vitamin D gene pathway polymorphisms and risk of colorectal, breast, and prostate cancer. Annu Rev Nutr. 2009;29:111-32.

213. Bahadoran Z, Mirmiran P, Azizi F. Fast Food Pattern and CMD: A Review of Current Studies. Health Promotion Perspectives. 2015;5(4):231-40.

214. Mazidi M, Speakman J.R. Impact of obesity and ozone on the association between particulate air pollution and cardiovascular disease and stroke mortality among US adults. J Am Heart Assoc. 2018;7(11). https://doi.org/10. 1161/JAHA.117.008006

\section{Publisher's Note}

Springer Nature remains neutral with regard to jurisdictional claims in published maps and institutional affiliations.

\section{Ready to submit your research? Choose BMC and benefit from:}

- fast, convenient online submission

- thorough peer review by experienced researchers in your field

- rapid publication on acceptance

- support for research data, including large and complex data types

- gold Open Access which fosters wider collaboration and increased citations

- maximum visibility for your research: over $100 \mathrm{M}$ website views per year

At $\mathrm{BMC}$, research is always in progress.

Learn more biomedcentral.com/submissions 